\title{
Crop evapotranspiration in the Nile Delta under different irrigation methods
}

Michiaki Sugita ${ }^{1}$, Akihiro Matsuno ${ }^{2}$, Rushdi M.M. El-Kilani ${ }^{3,4}$, Ahmed Abdel-Fattah ${ }^{5}$, and M.A. Mahmoud ${ }^{6}$

${ }^{1}$ Faculty of Life and Environmental Sciences, University of Tsukuba, Tsukuba, Ibaraki, Japan

${ }^{2}$ Graduate School of Life and Environmental Sciences, University of Tsukuba, Tsukuba, Ibaraki, Japan

${ }^{3}$ Soils Department, Faculty of Agriculture, Cairo University, Giza, Egypt

${ }^{4}$ Environmental Physics and Chemodynamics Lab, Cairo University Research Park (CURP), Faculty of Agriculture, Cairo University, Giza, Egypt.

${ }^{5}$ Water Management Research Institute, National Water Research Center, Egypt,

${ }^{6}$ Water requirements and Field Irrigation Department, Soils Water \&Environment Research Institute, Agriculture Research Center, Egypt

Correspondence to: Michiaki Sugita, Faculty of Life \& Environmental Sciences, University of Tsukuba, Tsukuba, Ibaraki 305-8572, Japan. E-mail:

sugita@geoenv.tsukuba.ac.jp 
Abstract Eddy correlation measurements within the Nile Delta allowed the determination of evapotranspiration $(E)$ for seven crops (rice, maize, cotton, sugar beets, berseem, wheat, and faba beans) using basin irrigation (BI), furrow irrigation (FI), BI with increased intervals $\left(\mathrm{BI}_{\mathrm{i}}\right)$, FI with increased intervals $\left(\mathrm{FI}_{\mathrm{i}}\right)$, strip irrigation $(\mathrm{SI})$, and drip irrigation (DI). Total $E$ values over the cropping season for rice (BI, BIi) were the highest ( $>600 \mathrm{~mm}$ ) while those for sugar beets (DI), maize (SI and DI), and berseem (BIi) were the lowest $(<250 \mathrm{~mm})$. Differences were due to a combination of atmospheric demand, soil moisture, the presence of surface standing water, root depth, and the length and timing of the cropping season. The DI and SI methods had an advantage for water saving, while the FIi and BIi methods were effective for crops with shallow root lengths. Estimated annual $E$ was $566-828 \mathrm{~mm} /$ year (water-saving irrigation) and 875-1225 mm/year (conventional irrigation).

Keywords Nile Delta; evapotranspiration; crop coefficient; eddy correlation; irrigation; summer and winter crops 


\section{INTRODUCTION}

Agriculture is the largest water consumer in many parts of the world (e.g., Turner et al. 2004). Although a certain portion of water withdrawal by agriculture is returned to surface water or groundwater, much is consumed by evapotranspiration. As such, efforts have been made to determine accurate evapotranspiration for various crops under different growing conditions. However, to date, evapotranspiration measurements for crop fields have largely been determined using the soil water balance method or the lysimeter method. In comparison to other methods, micrometeorological approaches such as the eddy correlation method have been infrequently used (Zwart and Bastiaanssen 2004; Farahani et al. 2007, Sugita et al. 2014, 2015), although the eddy correlation method is currently considered to be the most accurate method with the largest time resolution (Foken 2008) provided that careful attention is given to measurements and data processing. Also, to date, less attention has been paid to hydrological processes related to evapotranspiration within crop fields as compared to other types of surfaces. Such a lack of attention to crops has likely resulted because crop evapotranspiration has largely been addressed in agronomy subdisciplines such as crop science, agricultural meteorology, or agricultural engineering where the main concern is generally crop yield and where evapotranspiration is regarded as a factor affecting crop yield. Another reason for the lack of investigation could be related to the mismatch of time scales for hydrological processes (often hours to $10^{0} \mathrm{~d}$ ) as compared to those for evapotranspiration, generally determined using the soil water balance approach $\left(10^{1} \mathrm{~d}\right)$ that makes it difficult to assess hydrological processes in relation to evapotranspiration. 
For this study, we surveyed an area of the Nile Delta in Egypt (see Section 2.1 below) where crop fields occupy $\geq 70 \%$ of the area, where agriculture water use accounted for $82 \%$ of total water use from 2011-12 (Central Agency for Public Mobilization and Statistics 2014), and where the evapotranspiration of various crops has been determined either by applying an estimation formula or by considering the water balance of a crop field or a lysimeter but not micrometeorological methods (see Table 1 for previous studies within the Nile Delta; also see Rana and Katerji (2000) for a review of evapotranspiration measurements in Mediterranean climate areas). For example, ElShal (1966) applied the soil water balance method in order to estimate the evapotranspiration of various crops. Swelam et al. (2010) reported evapotranspiration for wheat using a weighing lysimeter installed in a crop field. In these studies, hydrological processes were not studied for the purpose of interpreting derived amounts of evapotranspiration. Also, in these studies, available evapotranspiration was obtained using the conventional irrigation method. Since, in today's world, crop evapotranspiraion using newer irrigation methods, such as drip irrigation, is often needed for future water use planning and management, updating and improving our knowledge of crop evapotranspiration based on micrometeorological methods, together with measurements of hydrological processes using various irrigation methods, is desirable and even necessary.

Due to the lack of micrometeorological measurements for crop evapotranspiration under various irrigation methods in the Nile Delta, we performed this study with primary objectives of determining a daily mean and total $E$ values for major crops cultivated using various irrigation methods by means of the eddy correlation method. Using observations 
and analyses of hydrologic processes within crop fields, we, secondly, clarified factors that cause $E$ differences for various crops and irrigation methods. Thus, the motivation of our study was largely scientific. However, the outcome of this study should have a wide range of practical applications. For example, since they provide information on when, where, and how water is consumed by evapotranspiration or lost to groundwater, investigations of hydrological processes are useful not only for evapotranspiration analyses but also for improving irrigation design in order to reduce water use. In a similar manner, based on precise estimates for the water consumption required for a particular crop or a particular irrigation method, factual water use in agriculture relative to water rights (often based on historic consumption) should become more clear, leading to more equitable use of water amongst competitors (see, e.g., Rice and White 1987).

\section{STUDY AREA AND OBSERVATION SITES}

\subsection{The Nile Delta}

The Nile Delta is located in an arid climate and has mean annual precipitation ranging from approximately $200 \mathrm{~mm} / \mathrm{y}$ near the Mediterranean coast, rapidly decreases inland, to $25 \mathrm{~mm} / \mathrm{y}$ in Cairo which is located on the southern edge of the delta (e.g., Griffiths 1972). The climate is quite uniform in most of the delta, except for areas near seas and deserts. Year-to-year changes in climate are small and, in general, quite stable due to its location within the sub-tropical high pressure belt (Griffiths 1972; also see Supplementary material, Section 1). 
According to Shalaby and Moghanm (2015), with the exception of western and eastern desert fringes and areas along the coast, soils within the Nile Delta can be classified as Entisols (Vertic Torrifluvents). As determined by combining images from four satellites (Fujihira 2014), the area containing the same soil type corresponds to the distribution of croplands within the Nile Delta. Thus, not only climate but soils in croplands within the Nile Delta can generally be assumed to be uniform with the exception of boundary zones between the delta and surrounding deserts and seas.

\subsection{Experimental fields}

To obtain detailed evapotranspiration data, three level crop fields (Sakha-A, Sakha-B, and Zankalon) with a size of $200 \times 200 \mathrm{~m}$ were established at two locations. The Sakha-A field $\left(31^{\circ} 5^{\prime} 54.70^{\prime \prime} \mathrm{N}\right.$ and $\left.30^{\circ} 55^{\prime} 21.00^{\prime \prime} \mathrm{E}\right)$ was located immediately north of the Sakha-B field ( $31^{\circ} 5^{\prime} 47.60^{\prime \prime} \mathrm{N}$ and $\left.30^{\circ} 55^{\prime} 21.20^{\prime \prime} \mathrm{E}\right)$ and are a part of the experimental field of the Agricultural Research Center near the city of Kafr El-Shaikh located in the central delta. The Zankalon field ( $30^{\circ} 34^{\prime} 50.04^{\prime \prime} \mathrm{N}$ and $\left.31^{\circ} 25^{\prime} 59.94^{\prime \prime} \mathrm{E}\right)$,

near the city of Zagazig, in the southeastern portion of the delta belongs to the Water Management Research Institute. All of the fields were located within agricultural areas that continuously extended at least $2 \mathrm{~km}$ (Sakha) and $0.8 \mathrm{~km}$ (Zankalon) in the dominant, northwest, wind direction.

Typical soil properties for Sakha were reported by Orii (2012) and Kubota et al. (2015); and the properties of Zankalon were reported by Kubtota (2014, personal comm.). Briefly, the clay content is approximately $50 \%$ throughout the soil profile, as deep as 1 
$\mathrm{m}$. The bulk density is high and is in the range of $1.4-1.7 \mathrm{~g} / \mathrm{cm}^{3}$. These variables are approximately the same as for the crop fields of surrounding areas.

\section{Methods}

\subsection{Crops, irrigation methods, and the drainage system}

Selection of the crops and irrigation methods used for our experiment, which began in the summer of 2010 and continued through the 2014 cropping season, is summarized in Table 2. Three major summer crops (rice, maize, and cotton) and four major winter crops (wheat, berseem, faba beans, and sugar beets) were chosen for our study based on their relevance in terms of cultivation area and historical significance (e.g., Brown 1955) in Egypt. These crops occupied 55\% and $83 \%$ of the cropland in the Nile Delta during the summer and winter, respectively, of 2012 (see Fig. S1 in the Supplementary material, Section 8 for annual changes in the cultivation areas for summer and winter crops).

Surface irrigation and drip irrigation (DI) were employed. Surface irrigation methods included: 1) furrow irrigation (FI), 2) basin irrigation (BI), 3) strip irrigation (SI), 4) FI with increased irrigation intervals $\left(\mathrm{FI}_{\mathrm{i}}\right)$, and 5) $\mathrm{BI}$ with increased irrigation intervals $\left(\mathrm{BI}_{\mathrm{i}}\right)$. The FI and $\mathrm{BI}$ methods are conventional and are currently in use in the Nile Delta (see, e.g., Strelkoff et al. 1999) while the other methods are new to the area and are being tested for their capacity to save water (El-Kilani and Sugita 2017). With the exception of the DI method, the field was divided into two sections and each section was encompassed by a dyke. The design for each method, including the dimensions of 
planting beds and furrows, laterals and emitters, etc., is provided in Table S1 in the Supplementary material, Section 5.

The applied amount of irrigation water is provided in Table 2, and was based on an experimental design (Supplementary material, Table S2) determined from Egyptian standards for each crop and adjusted for the specific requirements of experiments (Maruyama, personal comm. 2015; Maruyama et al. 2017). For actual irrigation implementation, the amount and timing of irrigation were modified from the experimental design, whenever necessary, in order to accommodate factors that changed for different years and locations, such as winter periodic rainfall and the availability of workers and water (see Satoh and El-Gamal (2017) for water management practices in the Nile Delta).

The standard tile drainage system of Egypt (e.g., Abdel-Dayem 1987, Amer and de Ridder 1989, Kubota et al. 2017) was adopted in the three fields. Lateral drains, buried at $1.35-\mathrm{m}$ in depth at an approximate $20 \mathrm{~m}$ horizontal interval, extended to a length of $100 \mathrm{~m}$ from the main collectors in two opposite directions. Collectors were connected to drainage canals.

\subsection{Eddy correlation measurements of evapotranspiration}

To derive evapotranspiration, $E$, together with frictional velocity and sensible heat flux using the eddy correlation method (Table 3), turbulence measurements of wind velocities, humidity, and temperature were made continuously using sensors installed at the top of a $5 \mathrm{~m}$ tower constructed at the center of each field. A standard procedure (e.g., Lee et al. 2004, AsiaFlux Steering Committee 2007) was applied in order to produce flux 
data from raw turbulence measurements (for details, see Supplementary material, Section 2). In the discussion that follows, we mainly analyse daily evaporation.

\subsection{Apparent crop coefficient}

As mentioned, climate and soil conditions within crop fields in the delta are quite uniform and year-to-year climate variability is small. Thus, a direct comparison of $E$ values measured for different years and locations is likely acceptable. Nevertheless, to further enhance the credibility of comparisons, reference crop evapotranspiration, $E_{0}$, as defined by the Food and Agricultural Organization (FAO) (Allen et al. 1998):

$$
L_{\mathrm{e}} E_{0}=\frac{\Delta\left(R_{\mathrm{n}}-G\right)+\rho_{C_{\mathrm{p}}}\left(e_{\mathrm{s}}\left(T_{\mathrm{a}}\right)-e_{\mathrm{a}}\right) / r_{\mathrm{av}}}{\Delta+\gamma\left(1+r_{\mathrm{s}} / r_{\mathrm{av}}\right)}
$$

was introduced and the daily apparent crop coefficient, $K_{\mathrm{ca}}=E / E_{0}$, was determined. $K_{\mathrm{ca}}$ is called apparent because it is different from the crop coefficient, $K_{\mathrm{c}}$, as defined by the FAO. $K_{\mathrm{c}}$ is generally, but not always, defined for $E$ under optimum soil water conditions, while $K_{\text {ca }}$ reflects not only the difference due to a crop but also the soil water condition reflecting the adopted irrigation method.

In equation (1), $\rho$ is the density of the air; $c_{\mathrm{p}}$ is the specific heat of air at constant pressure; $r_{\mathrm{s}}$ is the surface resistance that is set equal to $70 \mathrm{~s} / \mathrm{m} ; r_{\mathrm{av}}$ is the aerodynamic resistance formulated using the wind speed at $2 \mathrm{~m}, u_{2}$, as $208 / u_{2}(\mathrm{~s} / \mathrm{m}) ; \Delta$ is the rate of change of the saturation vapor pressure, $e_{\mathrm{s}}$, at air temperature, $T_{a}$; and $e_{\mathrm{a}}$ is the atmospheric vapor pressure. To avoid a difference in $E_{0}$ resulting from surface conditions, net radiation $R_{\mathrm{n}}$ was estimated from measured downward short- and long-wave radiation, $R_{\mathrm{sd}}$ 
and $R_{\mathrm{ld}}$, respectively, the upward short-wave radiation, $R_{\mathrm{su}}$, estimated using a fixed albedo of $\alpha=0.23, R_{\mathrm{lu}}=\sigma T_{\mathrm{a}}^{4}$ (Allen et al. 1998), and soil heat flux $G$ from $C_{\mathrm{R}} \times R_{\mathrm{n}}$, with $C_{\mathrm{R}}=$ 0.1 for a grass surface (e.g., Brutsaert 2005).

In addition to daily values of $K_{\mathrm{ca}}$, the mean value over a certain period of time, $T$, was defined as $K_{\text {ca, } \mathrm{T}}=E_{\mathrm{T}} / E_{0, \mathrm{~T}}$, where $E_{\mathrm{T}}=\int E \mathrm{~d} t$ and $E_{0, \mathrm{~T}}=\int E_{0} \mathrm{~d} t$ over the period $T$. For the analysis, the following descriptions were employed: $T=$ "tot" for the total cropping season (Table 1); $T=$ "ini" for the initial stage; $T=$ "dev" for the crop development stage; $T=$ "mid" for the mid-season stage; $T=$ "late" for the late season stage (Allen et al. 1998); $T=$ "fallow, s" for the spring fallow season; $T=$ "fallow, f" for the fall fallow season; and $T=$ "annual" for one year.

A small difference in the length of the cropping season for the same crop but for different years and locations was considered using the following procedure. First, standard values of $E_{0, \text { tot }}$ and the cropping period for each crop were determined using the average reference crop evapotranspiration, $\overline{E_{0, \text { tot }}}$, and the average cropping period, $\bar{N}$ (d), for all available $E_{0, \text { tot }}$ and the $N$ values for each crop. These values were used to derive the adjusted $E_{\text {tot }}(\mathrm{mm})$ and the mean daily $\bar{E}(\mathrm{~mm} / \mathrm{d})$ used in the analysis based on:

$$
\begin{gathered}
E_{\text {tot }}=K_{\mathrm{ca}, \text { tot }} \overline{E_{0, \text { tot }}}, \\
\bar{E}=E_{\text {tot }} / \bar{N} .
\end{gathered}
$$

When multiple results were obtained for a given combination of crop and irrigation methods, the means of (2) and (3) were determined and used for the analysis. 


\subsection{Additional related variables for explaining the factors controlling evapotranspiration}

Additional variables measured during the experiment are summarized in Table 3. Briefly, these variables were: (1) related to crop growth, including the mean crop height $\left(h_{0}\right)$, the leaf area index $\left(L_{\mathrm{A}}\right)$, the canopy cover fraction $\left(f_{\mathrm{v}}\right)$, the crop yield, and the root zone depth $\left(z_{\mathrm{rz}}\right) ;(2)$ related to the water availability for crops and evapotranspiration, such as the soil water content $(\theta)$, the groundwater level $\left(z_{\mathrm{GW}}\right)$, and the irrigation amount $\left(P_{\mathrm{i}}\right)$; (3) related to general meteorological variables, including air temperature $\left(T_{\mathrm{a}}\right)$, relative humidity $(r)$, wind speed $(u)$, and atmospheric pressure; (4) the four radiation components; and (5) the energy balance components.

\subsection{Annual evapotranspiration}

Annual evapotranspiration, $E_{\text {annual }}$, was estimated as the sum of the following four terms:

$$
\begin{aligned}
& E_{\text {annual }}=E_{\text {summer }}+E_{\text {winter }}+E_{\text {fallow }, \mathrm{s}}+E_{\text {fallow }, \mathrm{f}} \\
& =(\bar{N} \bar{E})_{\text {summer }}+(\bar{N} \bar{E})_{\text {winter }}+(\bar{N} \bar{E})_{\text {fallow }, \mathrm{s}}+(\bar{N} \bar{E})_{\text {fallow }, \mathrm{f}}
\end{aligned}
$$

for a given combination of summer and winter crops, and irrigation method(s). The lengths of the two fallow seasons were determined using:

$$
(N)_{\text {fallow, }}=(N)_{\text {fallow, }}=1 / 2\left[365-(\bar{N})_{\text {summer }}-(\bar{N})_{\text {winter }}\right] \text { since their average lengths }
$$

during the observation period were determined to be the same $(=43 \mathrm{~d})$. 


\section{RESULTS}

The values of $E_{\text {tot }}\left(\right.$ Panel A), $\bar{E}$ (Panel B), and $K_{\text {ca,tot }}$ (Panel C) for the various crops and for the various irrigation methods are compared in Fig.1. The left side provides information for summer crops and the right side provides information for winter crops.

\subsection{Summer crops}

\subsubsection{Differences due to crop selection}

Clear from Fig. 1 is that rice consumed more water as evapotranspiration than other crops. The $K_{\text {catot }}$ value of rice (BI) was $56 \%$ larger than that of maize (FI). In a similar manner, the $E_{\text {tot }}$ and $\bar{E}$ of rice (BI) were $81 \%$ and $42 \%$ larger than those of maize (FI), respectively.

The difference in $E_{\text {tot }}$ was partly due to the longer cropping season of rice ( $\bar{N}=$ $125 \mathrm{~d})$ as compared to maize $(\bar{N}=98 \mathrm{~d})$. However, the main factor was the difference in $E$ during the earlier cropping stage. As shown in Fig. 2(f), the daily values of $E$ and $K_{\text {ca }}$ for maize (FI) increased quickly versus $E_{0}$ for each irrigation event and then gradually decreased with time during early stages of the cropping season, while they remained more or less constant during later stages almost regardless of irrigation events. This result likely occurred because soil evaporation, $E_{\mathrm{g}}$, dominated $E$ during the earlier stages of the cropping season due to small vegetation cover. Soil evaporation tends to be more easily affected by $\theta$ changes near the surface. Indeed, wetting and drying cycles can clearly be 
observed within the soil column, particularly near the surface, in response to irrigation events and groundwater level, $z_{\mathrm{GW}}$, increases (Fig. 3(f)). Additionally, the shallow root zone depth, $z_{\mathrm{rz}}$, during this stage (Fig. 3(f)) helped to suppress transpiration when $\theta$ decreased within the root zone. On the other hand, for later stages it can be speculated that $E_{\mathrm{g}}$ gradually decreased and that transpiration became the main component of $E$ as $f_{\mathrm{c}}$ and $z_{\mathrm{rz}}$ increased (Fig. 3(f)). The larger $z_{\mathrm{rz}}$ allowed plants to make use of soil water at deeper depths, and, as a result, $E$ was minimally influenced by soil moisture fluctuations near the surface.

In contrast, the values of $E, K_{\mathrm{ca}}$, and $\theta$ remained high throughout the cropping season of rice (Figs 2(a) and 3(a)) due to the presence of standing water on the soil surface resulting from the $\mathrm{BI}$ method. Although $z_{\mathrm{GW}}$ measurements were not available for this cropping season, it appears that the soil column was completely saturated.

These differences are also clear in Table 4, where the $K_{\text {ca }}$ and $\bar{E}$ values for various growth stages are listed for maize (FI) and rice (BI). Smaller $\bar{E}$ and $K_{\text {ca values for maize }}$ during the initial stage can clearly be seen as compared to those of rice. Comparisons are also provided in Table 4 for average values of the Bowen ratio $(\overline{B o})$, albedo $(\bar{\alpha})$, upward longwave radiation $\left(\overline{R_{\mathrm{lu}}}\right)$, and net radiation $\left(\overline{R_{\mathrm{n}}}\right)$. A striking finding was that the $\overline{B o}$ of maize for the initial stage was much larger than that of the other stages of maize, and any of the growth stages of rice. This finding is another indication of soil surface dryness between irrigation events during the initial stage.

Cotton (SI) consumed less daily water as $\bar{E}$ than maize (SI) but more water as $E_{\text {tot }}$ (Fig. 1). The larger $E_{\text {tot }}$ of cotton was the result of the longer cropping season of cotton 
(approximately 169 d) as compared to other crops (98-125d). On the other hand, the difference in $\bar{E}$ was mainly due to smaller $K_{\text {ca }}$ and daily $\bar{E}$ values for cotton than those of maize during the initial and development growth stages (Table 5, Fig. 2(b) and Fig. 2 (d)). $\overline{B o}$ values for these stages of cotton were also quite large (Table 5), indicating surface soil dryness. Unfortunately, vegetation growth data such as that for the cover fraction and the leaf area index of cotton were not available for comparison. However, we suspect that the surface coverage of cotton was smaller than that of maize during the early stages and that the exposed soil surface tended to easily become dry. Such a hypothesis is consistent with general knowledge that initial growth for cotton is slow (e.g., National Cotton Council of America 2015).

\subsubsection{Differences due to irrigation methods}

For maize, a comparison was possible for all irrigation methods; and the $E_{\text {tot, }} \bar{E}$, and $K_{\text {ca,tot }}$ values all indicated similar differences (Fig. 1). One can immediately notice that Fi and FIi did not produce markedly different $E_{\text {tot }}$ values, likely because the roots of maize (FIi) quickly developed (less than one month after seeding) to deeper depths where

$\theta>\theta_{\mathrm{f}}$ ( $\theta$ at field capacity) (Fig. 3(e)). Therefore, with the exception of the first month, maize (FIi) made use of soil water available at deeper depths even when the surface soil was dry between irrigation events. The fact that $\theta_{\mathrm{f}}$ appeared at a relatively shallow depth of $0.25-0.5$ is likely due to the shallow groundwater level and the clay rich soils common within the Nile Delta. 
$E_{\text {tot, }} \bar{E}$, and $K_{\text {ca,tot }}$ values obtained using the SI method and those obtained using the DI method were, respectively, $66 \%$ and $58 \%$ of those obtained using the FI method (Fig. 1). The differences can be explained by Figs 2 and 3. $\theta$ for DI and SI (Figs 3(c) and 3(d)) was, in general, much smaller than $\theta$ for $\mathrm{FI}_{\mathrm{i}}$ and FI (Figs 3(e) and 3(f)). A larger $z_{\mathrm{GW}}$ value can also be observed for DI. These differences caused different behaviours of the magnitude and time changes of $E$ and $K_{\text {ca. }}$ Those for SI (Fig. 2(d)) were, in general, smaller than those for FI and FI (Figs 2(e) and 2(f)) although the course of the time changes was quite similar for these three methods, with quick and strong responses to irrigation events during earlier stages and more stable and steady behaviour during later stages. In contrast, those for the DI method were different (Fig.2(c)). The time changes were quite simple with slow increases of $E$ and $K_{\text {ca }}$ in response to root development (Figs 2(c) and 3(c)) but without clear responses to irrigation events.

For rice, a comparison between $\mathrm{BI}$ and $\mathrm{BI}$ i was possible (Fig. 1), and $E_{\text {tot }}$ and $K_{\text {ca,tot }}$ estimates for $\mathrm{BI}$ i were $78 \%$ of those cultivated using the BI method. The figure showing the change in $E, E_{0}$, and $K_{\text {ca }}$ for BIi (not shown) and a comparison to BI (Fig. 2(a)) indicated that the shapes of both time changes were similar but that the magnitude of $E$ and $K_{\mathrm{c}}$ for $\mathrm{BI}_{\mathrm{i}}$ was smaller than that for BI. We suspect that longer intervals of irrigation under $\mathrm{BI}_{\mathrm{i}}$ reduced the frequency of the presence of standing water as compared to that for BI. Unfortunately, due to a technical problem with the soil moisture sensors in saline soil (Supplementary material, Section 3, Sugita et al. 2016), $\theta$ values were not available for $\mathrm{BI}_{\mathrm{i}}$ so we could not verify this hypothesis.

\subsection{Winter crops}




\subsubsection{Differences due to crop selection}

The values of $K_{\text {ca,tot }}$ and $\bar{E}$ for wheat (BI) were, respectively, $14-16 \%$ and $22-28 \%$ larger than those for other crops cultivated using the same FI/BI methods, while the difference in $E_{\text {tot }}$ was small with the exception of faba beans (Fig.1). The difference in root development is likely to have contributed, at least in part, to the differences in $K_{\text {ca,tot }}$ and $\bar{E}$. The root system of wheat is known to develop vertically and to a greater depth (>1 m; e.g., Weaver et al. 1924 and Thorup-Kristensen et al. 2009) as compared to berseem and faba beans. Root density measurements obtained at the end of each cropping season (Fujimaki 2014, personal comm.) indicated that the root density of faba beans and berseem were almost zero at the lowest measurement depth of $-0.5 \mathrm{~m}$ while it was not for wheat. Therefore, wheat had an advantage in that it could make use of larger soil moisture at greater depths, resulting in larger values for $K_{\text {ca,tot }}$ and $\bar{E}$.

Since sugar beets are known to develop a main root down to 1.5-1.8 $\mathrm{m}$ (Dunham 1993, Hergert 2012), this explanation is not applicable to sugar beets, although, for our experiment, we did not conduct formal measurements of the root system of sugar beets. The smaller $K_{\text {ca,tot }}$ and $\bar{E}$ values of sugar beets, as compared to those of wheat, appeared to be due to slower initial growth for sugar beets (Seadh et al. 2013), which led to longer periods for the presence of a soil surface not covered by vegetation. As shown in Table 6 , the $\overline{B o}$ values of sugar beets during the initial and developmen stages were large, implying surface dryness, likely due to small vegetation cover. Thus, the $K_{\mathrm{ca}, \text { ini }}$ and $K_{\mathrm{ca} \text {,dev }}$ (and also $\bar{E}$ for these two stages) for sugar beets were smaller than those of wheat (also see Figs 4(c) and 4(d) for seasonal variations of $K_{\mathrm{ca}}$ and $E$ ). 
The difference in $E_{\text {tot }}$ between wheat and berseem or sugar beets was smaller than that of $\bar{E}$ and $K_{\text {ca,tot }}$ because the length of the cropping season of wheat (approximately $N=160 \mathrm{~d})$ is shorter than that of berseem $(N=196 \mathrm{~d})$ and sugar beets $(N=184 \mathrm{~d})$. On the other hand, the difference of $E_{\text {tot }}$ was approximately the same, with values of $\bar{E}$ and $K_{\text {ca,tot }}$ between wheat and faba beans because the cropping period of faba beans $(N=162$ d) is similar to that of wheat.

\subsubsection{Differences due to irrigation methods}

For sugar beets, the impact of adopting the FI and DI irrigation methods on evapotranspiration was considered. As Fig. 1 indicates, when the DI method was

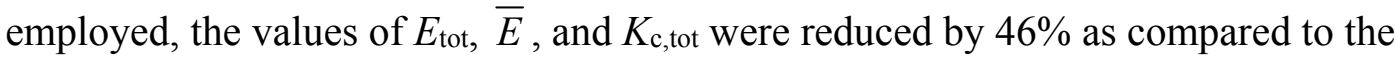
same values obtained using FI. For wheat and berseem, a comparison between BI and $\mathrm{BI}_{\mathrm{i}}$ was possible, and we determined large differences between these two crops. When berseem was cultivated under the Bli method, $E_{\text {tot }}$ values, as well as $K_{c}$, were smaller by $47 \%$ as compared to those of $\mathrm{BI}$, while they were larger by $7 \%$ for wheat. The differences appeared to have been caused by the difference in their root systems. As previously mentioned, the root system of wheat extends down to much deeper depths as compared to those of berseem. Therefore, the difference of $\theta$ near the surface caused by the two different irrigation methods of BI and BIi (Figs 5(b) and 5(c) for wheat and Figs 5(e) and 5(f) for berseem) did not result in a meaningful impact for wheat water consumption, while it did for berseem. 


\subsection{Differences between summer and winter crops}

In this section, we summarize the difference between winter and summer crops. Daily changes in the $E, E_{0}, K_{\mathrm{ca}}$, and $P_{\mathrm{i}}$ of winter crops (Fig. 4 ) were compared to those for summer crops (Fig. 2). A striking difference can be noticed regarding the impact of

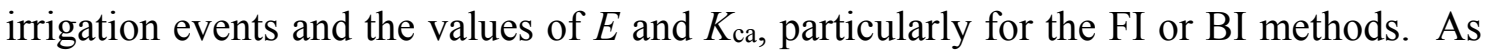
mentioned above, sudden increases for $E$ and $K_{\text {ca }}$ are clearly noticeable for maize (Figs 2(d), 2(e) and 2(f)) and, to a lesser extent, for cotton (Fig. 2(b)) during early cropping stages in response to irrigation events. Corresponding increases in soil moisture and in the water table can also be observed in Fig. 3. In contrast, this type of response for $E$ and $K_{\text {ca }}$ to irrigation events was not observed for all of the winter crops tested during our experiment (Fig. 4), even though the responses of soil moisture and the water table were as clear as those obtained for the summer cropping season.

The results can be understood based on the difference in atmospheric demand for evapotranspiration between the two seasons as compared to soil water storage in crop fields within the Nile Delta. For example, daily mean values for July (corresponding to the early cropping state during summer) were $\bar{E}=2.5 \mathrm{~mm} / \mathrm{d}$ and $\overline{E_{0}}=5.2 \mathrm{~mm} / \mathrm{d}$, while those in December (during the early cropping stages in winter) were $\bar{E}=1.2 \mathrm{~mm} / \mathrm{d}$ and $\overline{E_{0}}=1.4 \mathrm{~mm} / \mathrm{d}$ for 2013 at the Sakha-A field. Thus, $\bar{E} \approx \overline{E_{0}}$ for the winter crops, while $\bar{E}<\overline{E_{0}}$ for the summer crops.

Soil water storage, when the soil column is completely saturated just after irrigation, was determined from the saturated soil water content, $\theta_{\mathrm{s}}$, as $38 \mathrm{~mm}$ (for the soil layer over a depth range of 0-0.15 m), $193 \mathrm{~mm}(0-0.3 \mathrm{~m}), 368 \mathrm{~mm}(0-0.6 \mathrm{~m})$, and 730 
$\mathrm{mm}(0-1.2 \mathrm{~m})$. For $\theta_{\mathrm{f}}$, it was $29 \mathrm{~mm}, 141 \mathrm{~mm}, 282 \mathrm{~mm}$, and $564 \mathrm{~mm}$ for the respective layers. Thus, if initial storage with $\theta_{\mathrm{f}}$ is assumed, $21 \mathrm{~d}$ would be required for $\overline{E_{0}}$ to completely deplete soil water storage from $0-0.15 \mathrm{~m}$ during the winter cropping season. In contrast, this period would be only $5.6 \mathrm{~d}$ for the summer cropping season. In reality, before soil water is completely consumed, evapotranspiration begins to decrease. Such a scenario was often observed for maize. On the other hand, for winter crops, water storage was large enough in comparison to $\overline{E_{0}}$ so that a decrease of $\bar{E}$ was not observed.

\subsection{Annual evapotranspiration}

The estimated annual evapotranspiration values are provided for six combinations of crops and irrigation methods (Table 7). To reflect current conditions within the Nile Delta, we selected either the FI or BI method from conventional irrigation methods. The SI, DI, or Bli methods were adopted as water-saving irrigation methods.

With conventional irrigation methods, maize (FI) and fava beans (FI) produced a $E_{\text {annual }}=875 \mathrm{~mm} /$ year, which is likely closer to the minimum annual $E$ value of crop fields within the Nile Delta. When rice (BI) and wheat (BI) were selected, the result (= $1225 \mathrm{~mm} /$ year) should be the largest annual $E$ for conventional irrigation methods. As expected, the difference was as large as $350 \mathrm{~mm} /$ year. When water saving irrigation methods were introduced and berseem (BIi) or sugar beets (DI) were selected as winter crops, $E_{\text {annual }}$ became $816-828 \mathrm{~mm} /$ year for rice (BIi) and $566-584 \mathrm{~mm} /$ year for maize (DI) as the selected summer crop. 
An interesting finding was that the magnitude of $E_{\text {annual }}$ was much larger than the global mean evapotranspiration for areas over land surfaces (approximately 420-540 $\mathrm{mm} /$ year, e.g., Brutsaert 2005) and was compatible with that of natural vegetation in humid areas (e.g., Mueller et al. 2011). Therefore, it appears that the Nile Delta evaporates water in a similar manner to surfaces in humid areas, a finding clearly due to the large amount of water introduced from the Nile River due to irrigation practices.

Finally, since fallow evaporation accounts for as much as $10-20 \%$ of $E_{\text {annual }}$ in Table 7, the importance of fallow evaporation for water balance considerations of crop fields should be estimated. In general, fallow evaporation is not considered in crop evapotranspiration studies in agronomy.

As mentioned in the methods section, the average $\bar{E}$ for all fallow seasons during the experiment was used for estimating fallow evaporation. Since the time change of $\bar{E}$ and $K_{\text {ca }}$ during the fallow season can be different depending on the crop and irrigation method selected during the previous cropping season, this is a crude simplification. For example, a comparison between Figs 2(e) and 2(f) immediately verify such differences for the spring fallow season. As seen in Fig. 2(e), $\bar{E}$ kept decreasing while in Fig. 2(f) the rate of decrease was much smaller due to the timing of the last irrigation application during the previous winter cropping season. It was May 6 for Fig. 2(e) (also see Fig. 4(e) for the previous season) and April 2 for Fig. 2(f) (also see Fig. 4(c)). Thus, for a more precise estimation of annual evapotranspiration, refinement of fallow season treatment is necessary. 


\section{DISCUSSION}

The results presented above indicate that there are large differences for evapotranspiration between crop types, between summer and winter crops, and between different irrigation methods for the Nile Delta. As a result, depending on the selected combination of summer and winter crops and irrigation methods, annual evapotranspiration could also greatly differ (566-828 mm/year for water-saving irrigation methods and $875-1225 \mathrm{~mm} /$ year for conventional irrigation methods - the maximum difference of $659 \mathrm{~mm} / \mathrm{year}$ ). Differences in evapotranspiration resulted from the combination of atmospheric demand, soil moisture status, the presence of standing water on the surface, root depth, and the length and timing of the cropping season. Again, the relative importance of individual factors changed depending on the crop and the irrigation method.

Since our results are likely the first of their kind for the Nile Delta based on the eddy correlation method together with measurements of hydrological processes, they have the potential to be useful in various applications, including water resources assessment and planning. However, their limitations and reliability should be evaluated before they can be used with confidence. Therefore, below, we compare our results with those obtained in previous studies (Sections 5.1 and 5.2); which is useful for identifying the applicability of our results to other areas (Section 5.3).

\subsection{A comparison of crop evapotranspiration from previous studies based in the Nile}

\section{Delta}


We compared our results to those of previous studies within the Nile Delta. Since this study represents the first study that has applied the eddy correlation method to the Nile Delta, our comparison required us to compare results obtained from more traditional methods. Among such studies (Table 1), crop evapotranspiration determined by applying the soil water balance method to a $50 \mathrm{~m}^{2}$ plot cultivated with maize, wheat, or cotton (ElShal 1966, also reported by Shahin (1985)) was worth consideration. This comparison was beneficial because the experiment of El-Shal (1966) was conducted in Sakha, one of our study areas. Thus, a comparison of the two studies is a comparison between results obtained under the same soil and climate conditions. Results from this previous study were also provided for actual crop fields, which is also compatible with the results obtained from our study. Irrigation intervals and amounts were also, more or less, compatible with our results obtained using the FI method.

El-Shal (1966) obtained $\bar{E}=3.9-4.0 \mathrm{~mm} / \mathrm{d}$ and $E_{\text {tot }}=512-520 \mathrm{~mm}$ for late maize cultivated during the cropping season from July 30 - Dec. 8 . For a direct comparison, the

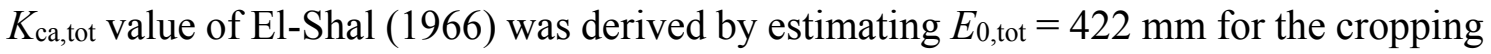
season of late maize, using our data obtained during 2011. The derived $K_{\text {ca,tot }}$ value was 1.2 , which is comparable to our $K_{\text {ca,tot }}$ value of 0.84 . Therefore, the evapotranspiration estimate by El-Shal (1966) is approximately $42 \%$ larger than that obtained during our study. In a similar manner, the results of El-Shal (1966) for cotton and wheat in the Sakha field were converted to a $K_{\text {ca,tot }}=0.89-0.91$ and a $K_{\text {ca,tot }}=0.80-0.85$, respectively, by applying the same procedure. Thus, the $K_{\text {ca }}$ value (and thus $E_{\text {tot }}$ ) was larger by $93-98 \%$ for cotton and smaller by $21-25 \%$ for wheat than our results obtained using the SI or BI irrigation methods. In other words, agreement was poor. 
The exact reason(s) for these large differences is (are) not known since the finer details of the experiments conducted by El-Shal (1966) are not clearly documented (e.g., depth to groundwater) or not available (e.g., crop information such as plant density). However, several reasons are possible for the differences in results. The first reason is possible overestimations of $E_{\text {tot }}$ due to the assumption, negligible drainage to deeper soil from the lowest measurement depth of $50 \mathrm{~cm}$, of El-Shal (1966) for the soil water balance method. The second reason is random errors introduced by the use of only three soil samples of $100 \mathrm{~cm}^{3}$ for determining mean soil moisture in the $10 \mathrm{~cm}$ depth layer of a 50 $\mathrm{m}^{2}$ plot. The third reason, specific only for maize, is that the target was late maze (Aug. to early Dec.) in the study by El-Shal (1966) while our target was regular summer maize (June-Sept. to early Oct.). Also, wheat tends to have a deeper root system and could have extended its roots below the $50 \mathrm{~cm}$ level, taking water from deeper soils. For cotton, a comparison with our $E_{\text {tot }}$ value, obtained under the SI irrigation method which presumably reduces water consumption, may have contributed to differences in the results. Finally, it is also possible that we over- or under-estimated daily $E$ values. Although we paid great attention to our measurements and post-data handling, our measurements are not perfect. In particular, the reliability of evapotranspiration data during the nighttime and during some winter periods is a concern and could be low since data gaps caused by the formation of dew on the sensor head of the gas analyser and by an electricity problem were filled in using various techniques (see Supplementary material, Section 2). However, a comparison with previous studies performed in other areas tends to indicate the general validity of our estimates (see Section 5.2 below). At any rate, given the poor agreement, performing independent eddy correlation 
measurements within the Nile Delta in order to formally validate our evapotranspiration measurements is desirable.

\subsection{A comparison of crop evapotranspiration reported in previous studies for other regions}

We also compared our values for crop evapotranspiration in the Nile Delta with those of other locations, although a wide range of conditions could affect the crop evapotranspiration values reported in these studies. For example, for the same crop, factors that are likely to affect evapotranspiration include climate, soil type, the irrigation method, the groundwater depth, the amount and timing of fertilizer application, weed/disease control, etc. Therefore, expecting a perfect match in conditions for comparing evapotranspiration values is not practical. Instead, we compared statistics that characterize the $E_{\text {tot }}$ of each crop to our values.

For this purpose, a large number of evapotranspiration measurements that reported $E_{\text {tot }}$ values measured in a crop field or in a test plot, but not in a pot experiment, were gathered from recent papers published in the international literature. $E_{\text {tot }}$ values were obtained from the review paper of Zwart and Bastiaanssen (2004) for wheat (number of $E_{\text {tot }}$ values, $\left.n=325\right)$, rice $(n=101)$, cotton $(n=112)$, and maize $(n=198)$, and through a literature search for berseem $(n=27)$, faba beans $(n=132)$, and sugar beets $(n=54)$ (see Table S3 in the Supplementary material, Section 7 for the details of each study). Statistics (the 10th, 25th, 50th, 75th, and 90th percentile values) determined for each crop are provided in Fig. 1 as a box-whisker plot. 
First, the range of $E_{\text {tot }}$ values for each crop was quite large and, yet, our $E_{\text {tot }}$ values, obtained under the conventional FI or BI irrigation methods, largely fell between the 25 th and 75 th percentiles. Thus, our $E_{\text {tot }}$ estimates are, in general, consistent with those of previous studies. Additionally, the $E_{\text {tot }}$ of rice, wheat, and faba beans were on the higher side of the percentile range, while maize was on the lower side. The values are in agreement with comparisons of crop yield statistics for Egypt and the world. For 2013, crop yields (kg/ha) for Egypt ranked 2nd amongst 118 rice producing countries, 11th amongst 125 wheat producing countries, 11th amongst 59 faba bean producing countries, and 28th amongst 167 maize producing countries according to FAOSTAT (FAO 2013). Agreement between values was natural since crop yield and evapotranspiration is known to be linearly correlated (e.g., Payero et al. 2006), although the ratio of crop yield to evapotranspiration is not exactly a constant and is affected by latitude, applied amounts of irrigation water, and the amount of applied nitrogen (e.g., Zwart and Bastiaanssen 2004). Again, this analysis tends to indicate the general validity of our estimates.

The same comparison was also used to examine whether or not the water-saving irrigation methods we found effective for the Nile Delta were similarly effective on a

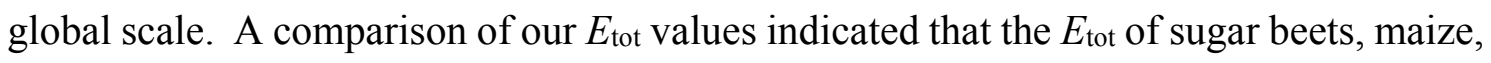
and cotton cultivated using the SI and DI methods within the Nile Delta were lower than the 10th percentile values, indicating the water-saving ability of these irrigation methods. The $E_{\text {tot }}$ of berseem obtained using the BIi method was also lower than the 10th percentile value, while that of wheat was closer to the 90th percentile value. Since the BIi and EIi methods are only effective for reducing water use for crops with shallow root zones, as discussed in Section 4.2.2, this result is reasonable. 


\subsection{Applicability to other cropping areas}

The above comparison indicates that our $E_{\text {tot }}$ estimates are, in general, consistent with those of previous studies, although the lack of close agreement with the results from earlier studies in Egypt is still a concern. Therefore, until independent validation using the eddy correlation method becomes available for the Nile Delta, our results should be used with certain reservation.

Despite their newness, our results can be used for many practical purposes not only for the Nile Delta but also for other areas. In addition to drought assessment, one immediate application for our results is water allocation planning. In many countries, to meet increasing water demand amongst competing sectors, water resources planning (e.g., the NWRP Project 2005) requires assessments of current water use and future water allocation. For estimations of water consumption by the agricultural sector, crop evapotranspiration is often derived by applying estimation schemes, such as (1), using the crop coefficients of Allen et al. (1998) with possible adjustments for the local environment. To not only estimate water demand for irrigation but to also provide estimates for the possible water withdrawal required from canals in relation to water availability in a watershed, in some cases, hydrological models are used together with crop models (e.g., McNider et al. 2015). For both cases, calibrating model parameters and, sometimes, modifying models or schemes to reflect local conditions is often necessary. Thus, the availability of $E_{\text {tot }}$ or $K_{\text {ca }}$ values, as well as information related to locally determined hydrological processes or values determined for similar 
environments, allows improved water allocation planning. The question then becomes: What variables should be similar so our results can be applied to other areas?

In general, climate, geomorphology, soils, and the availability of water (i.e., depth to groundwater or closeness to rivers and lakes) are important because these parameters usually interact with one another to create a particular environment for a crop field. However, differences in climate alone can be mitigated, to some extent, by the use of $K_{\mathrm{ca}}$ instead of $E$ when applying our results to areas with different climates. On the other hand, soil conditions, geomorphic features, and water availability are more difficult to understand. Soil types influence crop growth through the availability of soil water and nutrients. The geomorphology of the area where a crop field is located influences, and sometimes determines, soil type and water availability. Therefore, narrowing potential areas with similar geomorphology, soils, and water availability where our results can safely be applied was a good idea. One such area with a similar environment, among others, is a crop field developed on a delta that is characterized by extended flat surfaces, easy access to surface water, the presence of shallow groundwater, and clay-rich soils. Deltas are not only important for agriculture, due to their fertile soils; they are also important for other industries. Therefore, competition for land and water is often a major problem in these areas (e.g., Bucx et al. 2010, Evans 2012) and, yet, to our knowledge, there are no combined or detailed studies related to evapotranspiration and hydrological processes for a delta. Since equitable water allocation is essential for making better use of scarce water resources, our results could be useful for filling in such gaps in knowledge. 
Finally, some implications of our study in terms of water-saving irrigation are also worth mentioning. As indicated above, the DI and SI irrigation methods and those with increased irrigation intervals were found to be effective (at least for some crops) for reducing water consumption. Amongst irrigation methods, the SI method appears promising because it does not require additional cost in relation to furrow irrigation. In contrast, the DI method requires initial and operating costs and it is not feasible to expect the large scale use of this method in developing countries. An increase in irrigation intervals does not require additional costs, but it does require well-coordinated crop field management for which educated human resources are required. Quite often, a lack of human resources is the major obstacle in developing countries. Thus, in developing countries, the SI method is a good alternative to the furrow irrigation method. However, for this study, we only tested one version of a SI method. Therefore, finding optimum dimensions for the planting bed/furrow width for each crop is desirable. Our observations of hydrological processes during the SI method are useful for this purpose.

\section{CONCLUSIONDING REMARKS}

To determine crop evapotranspiration for major crops cultivated under different irrigation methods, we deployed eddy correlation systems from 2010 through 2014 for the first time in the Nile Delta. The general validation of the derived $E$ values were made by comparing them with $E$ values reported in previous studies. Our results indicated large differences for crop evapotranspiration depending on the type of crop and the corresponding irrigation method. Evapotranspiration of rice was by far the largest among the tested crops. Crop evapotranspiration using the SI and DI methods 
was found much smaller than that using the conventional irrigation methods while increasing irrigation intervals in furrows or basin irrigation reduced evapotranspiration for crops with shallow root systems. Therefore, annual evapotranspiration in crop fields within the Nile Delta could differ by as much as $659 \mathrm{~mm} / \mathrm{year}$ depending on crop selection and irrigation method.

Through detailed observations of hydrological processes, we were able to explain differences in evapotranspiration. Differences in evapotranspiration resulted due to a combination of atmospheric demand, soil moisture status, the presence of standing water on the surface, root depth, and the length and timing of the cropping season. The relative importance of each of these factors changed depending on the crop and the irrigation method employed. For example, for rice, the longer cropping season, the presence of ponded water and the continuous high soil moisture condition were found relevant.

Our results indicated that the FIi/BIi, SI, and DI methods were effective in reducing water consumption. When additional costs required in relation to conventional irrigation methods were considered, the SI method was identified as a promising choice. In order to consider overall water use efficiency of crop fields, however, other factors need to be considered. There are differences in the definition of efficiency to be maximized among researchers in different disciplines such as irrigation scientists, economists, or physiologists (Nair et al., 2013). Agronomists usually consider water use efficiency (WUE) defined as the yield per unit area divided by evapotranspiration. In this case, not only reducing evapotranspiration but also increasing crop yield is important to choose optimum irrigation methods. In the case of the Nile Delta, our 
results of $E_{\text {tot }}$ for various crops and for different irrigation methods have been used together with corresponding yield measurements by Maruyama et al. (2017). They concluded that the DI and SI methods produced higher WUE values than the furrow irrigation method for maize because of a larger yield in the case of DI, and in spite of a smaller yield for SI. From the viewpoint of irrigation scientists, it is important to achieve higher irrigation efficiency $e_{\mathrm{c}}$ defined as the ratio of crop evapotranspiration to inflow water into the field. El-Kilani and Sugita (2017) examined this for maize with our $E_{\text {tot }}$ values and found $e_{\mathrm{c}}=0.91$ for DI, 0.64 for SI, and 0.77 for FI. Thus the DI method produced the highest irrigation efficiency followed by the FI method. Overall, DI could be chosen as the optimum method of irrigation if additional costs can be accepted while SI should be considered if costs, water-saving ability, and water use efficiency are important.

Finally, the applicability of our results to other areas was discussed, particularly for the purpose of reducing water consumption in the agriculture sector and in regards to establishing more equitable water allocation within an area with increasing water demands in various sectors. Deltas were identified as potential regions where our results could be useful for various practical purposes such as drought assessment and water allocation planning.

\section{Acknowledgements}

Authors are grateful to Fujimaki, H. (Tottori University) for providing us with his soil moisture, root profiles and soil physics data, to Hoshino A for the soil hydraulic 
parameters, to Kubota, A. and Maruyama, S. (Univ. Tsukuba) for sharing their results on plant physiology and observation, to Fukuda, T., Tsuchihira, K., Irigaki Y. and Tsuji, I. (Univ. Tsukuba) for their participation in field observations, and to Osada, A., Kamitani, T., Sayed El Nehlak, Hassan Mohamed Abd El.Baki, and Hussein Al Nadar (WAT project office in Cairo, Japan International Cooperation Agency) among others for supporting the field observations for this study. Finally, the authors also express their appreciation to Satoh, M. (Univ. Tsukuba) without whose initiatives and leadership the experiment for this study would not have been possible.

\section{Funding}

This research has been supported and financed, in part, through a SATREPS project "Sustainable Systems for Food and Bio-energy Production with Water-saving Irrigation in the Egyptian Nile Basin” of JST/JICA, and also by JSPS KAKHNHI Grant Number 24241053 (the Japan Society for the Promotion of Science).

\section{REFERENCES}

Abdel-Dayem, M.S., 1987. Development of land drainage in Egypt. In: J. Vos ed. Proceedings of the $25^{\text {th }}$ International Course on Land Drainage: 25 years of Drainage Experience. Publication 42, International Institute for Land Reclamation and Improvement: Wageningen, The Netherlands, 195-204.

Allen, R.G., et al., 1998. Crop evapotranspiration - guidelines for computing crop water requirements. FAO Irrigation and Drainage Paper 56, Food and Agriculture 
Organization of the United Nations: Rome, Italy. (also Available from: http://www.fao.org/docrep/x0490e/x0490e00.htm\#Contents [Accessed 1 December 2016])

Amer, M.H. and de Ridder, N.A., 1989. Land Drainage in Egypt. Drainage Research Institute, Water Research Center, Ministry of Public Works and Water Resources: Cairo, Egypt.

AsiaFlux Steering Committee, ed., 2007. Practice of Flux Observations in Terrestrial Ecosystems. Available for AsiaFlux members from: http://www.asiaflux.net/ [Accessed 3 February, 2016].

Brown, C.H., 1955. Egyptian Cotton. Leonard Hill Books, Ltd.: London, UK.

Brutsaert, W., 2005. Hydrology: An Introduction. Cambridge University Press: Cambridge, UK.

Bucx, T., et al., 2010. Comparative Assessment of the Vulnerability and Resilience of 10 Deltas - Synthesis Report. Delta Alliance report number 1, Delta Alliance International: Delft-Wageningen, the Netherlands.

Central Agency for Public Mobilization and Statistics, 2014, Statistical Year Book 2014. Central Agency for Mobilization and Statistics: Cairo, Egypt.

Dunham, R.J., 1993. Water use and irrigation. In: D.A.Cooke and R.K. Scott, eds. The Sugar Beet Crop, Chapman \& Hall: London, 279-309.

El-Kilani, R.M.M. and Sugita, M., 2017. Irrigation methods and water requirements in the Nile Delta. In: M. Satoh and S. Aboulroos, eds. Irrigated Agriculture in EgyptPast, Present and Future. Springer, 125-151, doi: 10.1007/978-3-319-30216-4_6. 
El-Shal, M.I., 1966. Consumptive Use and Water Requirement for Some Major Crops in Egypt. Thesis (PhD). Faculty of Engineering, Cairo University.

Evans, G., 2012. Deltas: the fertile dustbins of the continents. Proceedings of the Geologist' Association, 123, 397-418, doi:10.1016/j.pgeola.2011.11.001.

FAO, 2013. FAOSTAT [online]. Available from: http://faostat.fao.org/site/291/default.aspx, [Accessed 12 July 2016].

Farahani, H.J., et al., 2007. Evapotranspiration: Progress in measurement and modeling in agriculture. Transactions of the ASABE, 50, 1627-1638.

Foken, T., 2008. Micrometeorology. Springer: Berlin, Germany.

Fujihira H. 2014. Land Cover Classification Mapping and Cropping Season Estimation in the Nile Delta Based on Satellite Remote Sensing. Thesis (MS), Graduate School of Life and Environmental Science, University of Tsukuba (in Japanese).

Griffiths, J.F., ed., 1972. Climate of Africa. Elsevier: Amsterdam, The Netherlands.

Hergert, G.W., 2012. Sugarbeet Nutrient Management. NebGuide G1459, Univ. Nebraska-Lincoln Extension, Institute of Agriculture and Natural Resources: Lincoln, Nebraska, USA.

Kubota, A., et al., 2015. Evaluation of intercropping system of maize and leguminous crops in the Nile Delta of Egypt. Tropical Agriculture and Development, 59, 14-19.

Kubota, A., et al., 2015. Water and salt movement in soils of the Nile Delta. In: M. Satoh and S. Aboulroos, eds. Irrigated Agriculture in Egypt- Past, Present and Future. Springer, 153186, doi: 10.1007/978-3-319-30216-4_7. 
Lee, X., Massan, W. and Law, B., 2004. Handbook of Micrometeorology. Kluwer Academic Publishers: Dordrecht, The Netherlands.

Maruyama, S., et al., 2017. Agricultural production-Cultivation techniques and farming. In: M. Satoh and S. Aboulroos, eds. Irrigated Agriculture in Egypt- Past, Present and Future. Springer, 225-254, doi: 10.1007/978-3-319-30216-4_9.

McNider, R.T., et al., 2015. An integrated crop and hydrologic modeling system to estimate hydrologic impacts of crop irrigation demands. Environmental Modelling \& Software, 72, 341-355.

Mueller, B., et al., 2011. Evaluation of global observations-based evapotranspiration datasets and IPCC AR4 simulations. Geophysical Research Letters, 38, L06402, doi: 10.1029/2010GL046230.

Nailr, S., Johnson, J., and Wang, C., 2013. Efficiency of irrigation water use: a review from the perspectives of multiple disciplines. Agronomy Journal, 105, 351-363.

National Cotton Council of America, 2015. Integrated Crop Management: Growth and Development of a Cotton Plant [online]. National Cotton Council of America. Available from: http://www.cotton.org/tech/ace/growth-and-development.cfm [Accessed 20 May 2015].

Orii, T., 2012. Effects of Irrigated Agriculture on Soil Salinity and Soil Clay Formation in Mid-Delta of Egypt. Thesis (MS), Graduate School of Life and Environmental Sciences, University of Tsukuba (in Japanese). 
Payero, J.O., et al., 2009. Effect of timing of a deficit-irrigation allocation on corn evapotranspiration, yield, water use efficiency and dry mass. Agricultural Water Management, 96, 1387-1397. doi:10.1016/j.agwat.2006.01.009

Rana, G. and Katerji, N., 2000. Measurement and estimation of actual evapotranspiration in the field under Mediterranean climate: a review. European Journal of Agronomy, 13, 125-153.

Rice, L. and White, M.D., 1998. Engineering Aspects of Water Law. John Wiley \& Sons: New York, US.

Satoh, M. and El-Gamal, T., 2017. Water management in the Delta. In: M. Satoh and S. Aboulroos, eds. Irrigated Agriculture in Egypt-Past, Present and Future. Springer, 187-224, doi: 10.1007/978-3-319-30216-4_8.

Seadh, S.E., et al., 2013. Productivity and quality of sugar beet as affecting by sowing methods, weed control treatments and Nitrogen fertilizer levels. Pakistan Journal of Biological Sciences, 16, 711-719. DOI: 10.3923/pjbs.2013.711.719

Shahin, M., 1985. Hydrology of the Nile Basin. Elsevier: Amsterdam, The Netherlands.

Shalaby, A. and Moghanm, F.S., 2015. Assessment of urban sprawl on agricultural soil of northern Nile Delta of Egypt using RS and GIS. Chinese Geographical Science, 25, 274-282, doi:10.1007/s11769-015-0748-z

Strelkoff, T.S., et al., 1999. Surface-irrigation evaluation models: application to level basins in Egypt. Transactions of the ASAE, 42, 1027-1036. 
Sugita, M., et al., 2014. Evaporation from Lake Kasumigaura: annual totals and variability in time and space. Hydrological Research Letters, 8, 103-107, doi:10.3178/hrl.8.103

Sugita, M., Yoshizawa, S., and Byambakhuu, I., 2015. Limiting factors for nomadic pastoralism in Mongolian steppe: a hydrologic perspective. Journal of Hydrology, 524, 455-467, doi: 10.1016/j.jhydrol.2015.02.050.

Sugita, M., et al., 2016. Continuous soil moisture monitoring under high salinity conditions by dielectric sensors: a reliability test. Tsukuba Geoenvironmental Sciences, 12, 17-22. Available from: http://hdl.handle.net/2241/00144875 [Accessed 6 March 2017]

Swelam, A., Snyder, R. and Ornag, M., 2010. Modeling Evapotranspiration of Applied Water in Egypt Delta: Calibrating SIMETAW model under Nile Delta Conditions [online]. The Center for Special Studies and Program, Alexandrina, Egypt, Available from: http://www.waterplan.water.ca.gov/docs/news/FinalReport_BibAlex_Sept2010.pdf [Accessed 22 March 2016].

Thorup-Kristensen, K., Cortasa, M.S. and Loges, R., 2009. Winter wheat roots grow twice as deep as spring wheat roots: is this important for $\mathrm{N}$ uptake and $\mathrm{N}$ leaching losses? Plant and Soil, 322, 101-114. doi: 10.1007/s11104-009-9898-z

Turner, K., et al., 2004. Economic Valuation of Water Resources in Agriculture [online] FAO Water Reports, 27, Food and Agriculture Organization of the United Nations, Rome. Available from: http://www.fao.org/docrep/007/y5582e/y5582e00.htm [Accessed 1 December 2016]/ 
Weaver, J.E., Kramer, J. and Reed, M., 1924. Development of root and shoot of winter wheat under field environment. Ecology, 5, 26-50.

Zwart, S.J. and Bastiaanssen, W.G.M., 2004. Review of measured crop water productivity values for irrigated wheat, rice, cotton and maize. Agricultural Water Management, 69, 115-133, doi:10.1016/j.agwat.2004.04.007 
Table 1 Previous studies on crop evapotranspiration based on field scale measurements in the Nile Delta

\begin{tabular}{|c|c|c|c|c|c|}
\hline Reference & Study area/site & $\begin{array}{l}\text { Target crops/size for } \\
\text { spatial averaging }\end{array}$ & Irrigation method & Method & Main findings ${ }^{*}$ \\
\hline $\begin{array}{l}\text { El-Shal } \\
\text { (1966), also } \\
\text { cited in } \\
\text { Shahin } \\
(1985)\end{array}$ & $\begin{array}{l}\text { Four sites } \\
\text { within the Nile } \\
\text { Delta }\end{array}$ & $\begin{array}{l}\text { Late maize, } \\
\text { cotton, and wheat }\end{array}$ & $\begin{array}{l}\text { - Conventional } \\
\text { irrigation } \\
\text { methods }\end{array}$ & $\begin{array}{l}\text { - } \begin{array}{l}\text { Soil water } \\
\text { balance method }\end{array}\end{array}$ & $\begin{array}{l}\text { Evapotranspiration } \\
\text { of each crop over } \\
\text { 10-day period was } \\
\text { determined. }\end{array}$ \\
\hline $\begin{array}{l}\text { Swelam et al. } \\
(2010)\end{array}$ & $\begin{array}{l}\text { Two sites in the } \\
\text { Nile Delta }\end{array}$ & - Maize and wheat & $\begin{array}{l}\text { - Conventional } \\
\text { irrigation } \\
\text { methods }\end{array}$ & $\begin{array}{l}\text { Soil water } \\
\text { balance method } \\
\text { (maize) }\end{array}$ & $\begin{array}{ll}\text { - Monthly } \\
\text { evapotranspiration } \\
\text { was obtained. } \\
K_{\text {ca values for four }} \\
\text { growth stages } \\
\text { were provided. }\end{array}$ \\
\hline Amer (2010) & $\begin{array}{l}\text { One site in the } \\
\text { northern part of } \\
\text { the Nile Delta }\end{array}$ & - Maize & $\begin{array}{l}\text { - Conventional } \\
\text { irrigation } \\
\text { method }\end{array}$ & $\begin{array}{l}\text { Soil water } \\
\text { balance method }\end{array}$ & $\begin{array}{l}\text { Monthly and total } \\
\text { evapotranspiration } \\
\text { values were } \\
\text { determined for } \\
\text { different level of } \\
\text { irrigation and } \\
\text { salinity }\end{array}$ \\
\hline This study & $\begin{array}{l}\text { Two sites in the } \\
\text { Nile Delta }\end{array}$ & $\begin{array}{l}\text { Maize, rice, } \\
\text { cotton (summer } \\
\text { crops) } \\
\text { wheat, sugar } \\
\text { beets, berseem, } \\
\text { and faba beans } \\
\text { (winter crops) }\end{array}$ & $\begin{array}{l}\text { Conventional } \\
\text { and water- } \\
\text { saving } \\
\text { irrigation } \\
\text { methods }\end{array}$ & $\begin{array}{l}\text { Eddy correlation } \\
\text { method }\end{array}$ & $\begin{array}{l}\text { Daily and total } \\
\text { evapotranspiration } \\
\text { values were } \\
\text { obtained. } \\
K_{\text {ca values for the }} \\
\text { cropping season } \\
\text { were determined. }\end{array}$ \\
\hline
\end{tabular}

${ }^{*}$ those related to our study purposes. $K_{\mathrm{ca}}$ is the apparent crop coefficient defined in section 3.3 
Table 2 Crop and irrigation selected for each cropping season and field

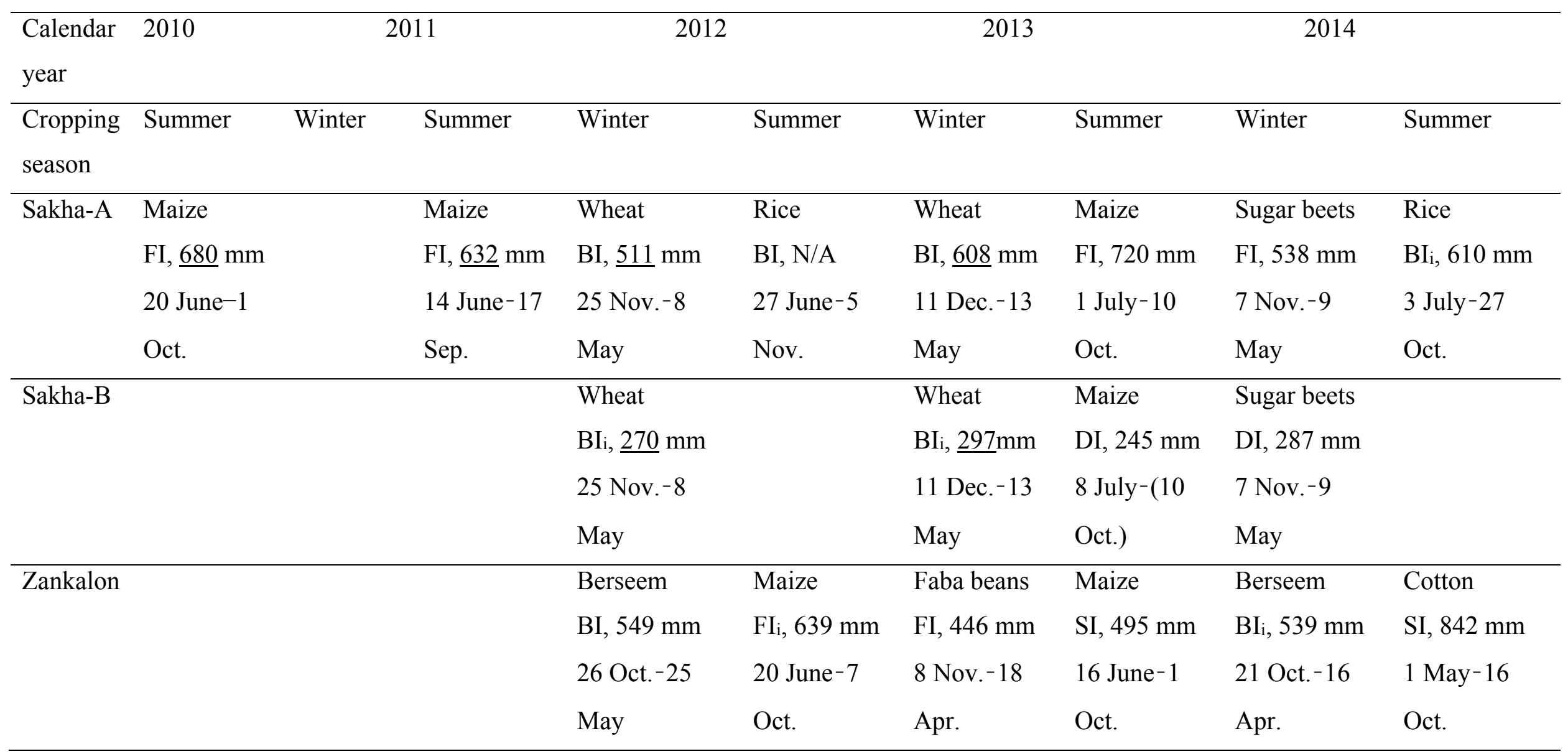

$1^{\text {st }}$ raw: crop, $2^{\text {nd }}$ raw: irrigation method and the total amount of irrigated water, $3^{\text {rd }}$ raw: cropping period. Underlined irrigation amounts include estimated values. 
Table 3 List of measurements and products obtained at each crop field

\begin{tabular}{|c|c|c|c|c|}
\hline Variables & Method of measurements & Sensor(s) & $\begin{array}{l}\text { Sensor } \\
\text { height } \\
\text { (m) }\end{array}$ & Time resolution \\
\hline Sensible heat flux, $H$ & Eddy correlation method & Gill Instruments, R3- & 5.78 & 30-min averages, continuous \\
\hline $\begin{array}{l}\text { Friction velocity, } u_{*} \\
\text { Evapotranspiration, } E\end{array}$ & & $\begin{array}{l}50 \text { and LI-Cor, LI- } \\
7500^{\dagger}\end{array}$ & & \\
\hline $\begin{array}{l}\text { Downward and upward short-wave } \\
\text { radiation, } R_{\mathrm{sd}}, R_{\mathrm{su}} \\
\text { Downward and upward long-wave } \\
\text { radiation, } R_{\mathrm{ld}}, R_{\mathrm{lu}}\end{array}$ & 4-component radiometer & $\begin{array}{l}\text { Hukseflux Thermal } \\
\text { Sensors, NR01 }\end{array}$ & 4.20 & \\
\hline Soil heat flux, $G$ & Soil heat flux plate & $\begin{array}{l}\text { Hukseflux Thermal } \\
\text { Sensors, HFP-01 }\end{array}$ & -0.03 & \\
\hline Atmospheric pressure, $p$ & Barometer & Vaisala, PTB210 & 0.8 & \\
\hline $\begin{array}{l}\text { Air temperature, } T_{\mathrm{a}} \\
\text { Relative humidity, } r\end{array}$ & $\begin{array}{l}\text { Ventilated hygrothermometers with } \\
\text { a radiation shield }\end{array}$ & Vaisala, HMP155 & $\begin{array}{l}0.5,1.0, \text { and } \\
3.0\end{array}$ & \\
\hline Amount of irrigation, $P_{\mathrm{i}}$ & $\begin{array}{l}\text { V-notch flow (surface irrigation) } \\
\text { and flow meter (drip irrigation) } \\
\text { measurements }\end{array}$ & $\mathrm{N} / \mathrm{A}$ & surface & At the time of irrigation event \\
\hline
\end{tabular}




\begin{tabular}{|c|c|c|c|c|}
\hline Groundwater level, $z_{\mathrm{gw}}$ & Pressure sensor & $\begin{array}{l}\text { Solint Canada Ltd, } \\
\text { Levelogger, Junior } \\
\text { Edge } 3001\end{array}$ & -1.35 & $\begin{array}{l}\text { 30-min, instantaneous, } \\
\text { continuous (2012-2014) }\end{array}$ \\
\hline Volumetric soil water content, $\theta$ & $\begin{array}{l}\text { Time Domain Reflectometry } \\
\text { (TDR) Soil Moisture Sensor }\end{array}$ & $\begin{array}{l}\text { Campbell Sci., Inc., } \\
\text { TDR-100 with CS630 } \\
\text { proves }\end{array}$ & $\begin{array}{l}-0.03 \\
-0.1,-0.2 \\
-0.4 \text { and } \\
-0.8\end{array}$ & $\begin{array}{l}\text { 30-min, instantaneous, } \\
\text { continuous } \\
\text { (Fujimaki, personal comm., } \\
\text { 2010-2014; see also } \\
\text { Supplementary material, } \\
\text { Section 3) }\end{array}$ \\
\hline $\begin{array}{l}\text { Soil hydraulics parameters ( } \theta \text { at } \\
\text { saturation } \theta_{\mathrm{s}} \text { and at filed capacity } \\
\theta_{\mathrm{f}}\end{array}$ & $\begin{array}{l}\text { Laboratory test with soil samples } \\
\text { taken from depths of } 0-5 \mathrm{~cm}, 7.5- \\
12.5 \mathrm{~cm}, 17.5-22.5 \mathrm{~cm} \text {, and } 77.5- \\
82.5 \mathrm{~cm} \text { at the Sakha-A field }\end{array}$ & $\mathrm{N} / \mathrm{A}$ & N/A & $\begin{array}{l}\text { One time soil sampling and } \\
\text { laboratory test (Hoshino, } \\
\text { personal comm., 2010) }\end{array}$ \\
\hline $\begin{array}{l}\text { Crop height, } h_{0} \\
\text { Leaf area index, } L_{\mathrm{A}}\end{array}$ & $\begin{array}{l}\text { In situ measurements } \\
\text { Canopy analyzer or leaf sampling } \\
\text { and measurements }\end{array}$ & $\begin{array}{l}\text { N/A } \\
\text { Li-Cor, LAI2200 and } \\
\text { LAI2000 }\end{array}$ & $\begin{array}{l}\text { above and } \\
\text { below } \\
\text { canopy }\end{array}$ & $\begin{array}{l}\text { Periodically during cropping } \\
\text { season in 2010-2012 } \\
\text { (Maruyama, personal comm., } \\
\text { 2010-2014) }\end{array}$ \\
\hline Crop yield & In situ measurements & N/A & & $\begin{array}{l}\text { At the end of cropping season } \\
\text { in 2010-2012 (Maruyama, } \\
\text { personal comm., 2010-2014) }\end{array}$ \\
\hline
\end{tabular}




\begin{tabular}{|c|c|c|c|c|}
\hline Canopy cover fraction, $f_{\mathrm{c}}$ & $\begin{array}{l}\text { Nadir-looking digital camera and } \\
\text { image processing }\end{array}$ & N/A & $\begin{array}{l}\text { above } \\
\text { canopy }\end{array}$ & Summer, 2011 \\
\hline Root zone depth, $z_{\mathrm{rz}}$ & In situ measurements & $\mathrm{N} / \mathrm{A}$ & & $\begin{array}{l}\text { One time measurement in the } \\
\text { summer cropping season in } \\
2012 \text { (Supplementary material, } \\
\text { Section 4) }\end{array}$ \\
\hline
\end{tabular}

${ }^{\dagger}$ Calibrated twice during the experiment. 


\begin{tabular}{|c|c|c|c|c|c|}
\hline Crop & Stage & Initial & Development & Mid-season & Late season \\
\hline \multirow{7}{*}{ Maize (FI, 2011) } & $\bar{E}(\mathrm{~mm} / \mathrm{d})$ & 2.6 & 4.5 & 5.2 & 4.1 \\
\hline & $K_{\text {ca }}$ & 0.51 & 0.95 & 1.20 & 1.10 \\
\hline & $\overline{B o}$ & 1.69 & 0.55 & 0.36 & 0.42 \\
\hline & $\overline{R_{\mathrm{n}}}\left(\mathrm{W} / \mathrm{m}^{2}\right)$ & 201 & 195 & 198 & 166 \\
\hline & $\bar{\alpha}$ & 0.11 & 0.13 & 0.14 & 0.15 \\
\hline & $\overline{R_{\mathrm{lu}}}\left(\mathrm{W} / \mathrm{m}^{2}\right)$ & 465 & 467 & 450 & 449 \\
\hline & Duration (d) & 22 & 48 & 8 & 18 \\
\hline \multirow{7}{*}{ Rice (BI, 2012) } & $\bar{E}(\mathrm{~mm} / \mathrm{d})$ & 5.1 & 6.4 & 6.5 & 3.2 \\
\hline & $K_{\mathrm{ca}}$ & 1.12 & 1.38 & 1.61 & 1.09 \\
\hline & $\overline{\overline{B o}}$ & 0.47 & 0.18 & 0.06 & 0.33 \\
\hline & $\overline{R_{\mathrm{n}}}\left(\mathrm{W} / \mathrm{m}^{2}\right)$ & 208 & 215 & 186 & 120 \\
\hline & $\bar{\alpha}$ & 0.079 & 0.092 & 0.097 & 0.13 \\
\hline & $\overline{R_{\mathrm{lu}}}\left(\mathrm{W} / \mathrm{m}^{2}\right)$ & 467 & 464 & 449 & 435 \\
\hline & Duration (d) & 30 & 30 & 32 & 40 \\
\hline
\end{tabular}

Note: $\bar{E}, K_{\mathrm{ca}}$ and duration are from Table 6.4 of El-Kilani and Sugita (2016). The duration of each stage was taken from Allen et al. (1998) and adjusted for the difference of total cropping period and crop growth. 
Table 5 Mean values of for the different growth stages of maize (SI) and cotton (SI)

\begin{tabular}{|c|c|c|c|c|c|}
\hline Crop & Stage & Initial & Development & Mid-season & Late season \\
\hline \multirow{7}{*}{ Maize (SI, 2013) } & $\bar{E}(\mathrm{~mm} / \mathrm{d})$ & 2.4 & 3.1 & 2.6 & 2.5 \\
\hline & $K_{\text {ca }}$ & 0.45 & 0.62 & 0.57 & 0.58 \\
\hline & $\overline{B o}$ & 1.72 & 0.97 & 0.88 & 0.73 \\
\hline & $\overline{R_{\mathrm{n}}}\left(\mathrm{W} / \mathrm{m}^{2}\right)$ & 188 & 203 & 200 & 177 \\
\hline & $\bar{\alpha}$ & 0.088 & 0.13 & 0.13 & 0.14 \\
\hline & $\overline{R_{\mathrm{lu}}}\left(\mathrm{W} / \mathrm{m}^{2}\right)$ & 481 & 468 & 452 & 446 \\
\hline & Duration (d) & 21 & 48 & 16 & 15 \\
\hline \multirow{7}{*}{ Cotton (SI, 2014) } & $\bar{E}(\mathrm{~mm} / \mathrm{d})$ & 1.2 & 1.8 & 3.4 & 2.1 \\
\hline & $K_{\text {ca }}$ & 0.22 & 0.31 & 0.67 & 0.56 \\
\hline & $\overline{\overline{B o}}$ & 2.38 & 1.70 & 0.44 & 0.50 \\
\hline & $\overline{R_{\mathrm{n}}}\left(\mathrm{W} / \mathrm{m}^{2}\right)$ & 178 & 193 & 194 & 167 \\
\hline & $\bar{\alpha}$ & 0.10 & 0.13 & 0.16 & 0.16 \\
\hline & $\overline{R_{\mathrm{lu}}}\left(\mathrm{W} / \mathrm{m}^{2}\right)$ & 457 & 472 & 465 & 445 \\
\hline & Duration $(\mathrm{d})$ & 26 & 43 & 52 & 48 \\
\hline
\end{tabular}

Note: The duration of each stage was taken from Allen et al. (1998) and adjusted for the difference of total cropping period and crop growth. 
Table 6 Mean values of for the different growth stages of wheat (BI) and sugar beets (FI)

\begin{tabular}{|c|c|c|c|c|c|}
\hline Crop & Stage & Initial & Development & Mid-season & Late season \\
\hline \multirow{7}{*}{ Wheat (BI, 2012-13) } & $\bar{E}(\mathrm{~mm} / \mathrm{d})$ & 1.7 & 2.8 & 3.9 & 2.8 \\
\hline & $K_{\mathrm{ca}}$ & 0.95 & 1.25 & 1.04 & 0.53 \\
\hline & $\overline{B o}$ & 0.50 & 0.37 & 0.61 & 1.59 \\
\hline & $\overline{R_{\mathrm{n}}}\left(\mathrm{W} / \mathrm{m}^{2}\right)$ & 75 & 108 & 181 & 208 \\
\hline & $\bar{\alpha}$ & 0.14 & 0.17 & 0.15 & 0.14 \\
\hline & $\overline{\overline{R_{\mathrm{lu}}}}\left(\mathrm{W} / \mathrm{m}^{2}\right)$ & 382 & 384 & 401 & 436 \\
\hline & Duration (d) & 19 & 90 & 26 & 19 \\
\hline \multirow{7}{*}{$\begin{array}{l}\text { Sugar beets (FI, } \\
2013-14)\end{array}$} & $\bar{E}(\mathrm{~mm} / \mathrm{d})$ & 1.1 & 1.3 & 2.8 & 4.9 \\
\hline & $K_{\text {ca }}$ & 0.68 & 0.87 & 1.01 & 0.97 \\
\hline & $\overline{B o}$ & 1.04 & 0.82 & 0.69 & 0.32 \\
\hline & $\overline{\overline{R_{\mathrm{n}}}}\left(\mathrm{W} / \mathrm{m}^{2}\right)$ & 82 & 85 & 142 & 189 \\
\hline & $\bar{\alpha}$ & 0.08 & 0.12 & 0.18 & 0.17 \\
\hline & $\overline{\overline{R_{\mathrm{lu}}}}\left(\mathrm{W} / \mathrm{m}^{2}\right)$ & 403 & 380 & 393 & 424 \\
\hline & Duration (d) & 36 & 60 & 64 & 24 \\
\hline
\end{tabular}

Note: The duration of each stage was taken from Allen et al. (1998) and adjusted for the difference of total cropping period and crop growth. 
Table 7 Estimated annual evapotranspiration for the selected crops and irrigation methods

\begin{tabular}{|c|c|c|c|c|c|c|}
\hline Crop and irrigation selection & $\begin{array}{c}E_{\text {summer }} \\
(\mathrm{mm})\end{array}$ & $\begin{array}{l}E_{\text {winter }} \\
(\mathrm{mm})\end{array}$ & $\begin{array}{l}E_{\text {fallow,s }} \\
(\mathrm{mm})\end{array}$ & $\begin{array}{l}E_{\text {fallow,f }} \\
(\mathrm{mm})\end{array}$ & $\begin{array}{c}E_{\text {annual }} \\
(\mathrm{mm} / \text { year })\end{array}$ & Remarks \\
\hline Maize $(\mathrm{FI})+$ fava bean $(\mathrm{FI})$ & 368 & 341 & 77 & 90 & 875 & \multirow{2}{*}{$\begin{array}{l}\text { Conventional } \\
\text { irrigation }\end{array}$} \\
\hline Rice $(\mathrm{BI})+$ wheat $(\mathrm{BI})$ & 667 & 431 & 58 & 68 & 1225 & \\
\hline Maize (SI) + berseem (BIi) & 245 & 226 & 52 & 61 & 584 & \multirow{4}{*}{$\begin{array}{c}\text { Water-saving } \\
\text { irrigation }\end{array}$} \\
\hline Maize (DI) + sugar beets (DI) & 215 & 220 & 61 & 71 & 566 & \\
\hline Rice (BIi) + berseem (BIi) & 520 & 226 & 33 & 38 & 816 & \\
\hline Rice $(\mathrm{BIi})++$ sugar beets $(\mathrm{DI})$ & 520 & 220 & 41 & 48 & 828 & \\
\hline
\end{tabular}


Figure caption

Fig. 1 Comparison of (a) $E_{\text {tot, }}$ (b) $\bar{E}$, and (c) $K_{\text {ca,tot }}$ over the cropping season for the selected crops and irrigation methods: summer crops (left), winter crops (right). The tabulated values can be found in Table 6.3 of El-Kilani and Sugita (2017). In (a), box-whisker plots are provided as an inset (for the same $y$-axes) and display the 10th, 25th, 50th, 75th, and 90th percentile values determined from the $E_{\text {tot }}$ values reported in previous studies, compared with those of our study. $E_{\text {tot }}$ values were obtained from Figure 2(b) of Zwart and Bastiaanssen (2004) for rice, maize, and cotton. The references for berseem, faba beans, and sugar beets are provided in the Supplementary material, Table S3.

Fig. 2 Changes in the daily values of $E, E_{0}, K_{\mathrm{ca}}$, and $P_{\mathrm{i}}$ for some of the selected summer crops, (a) rice (BI) in 2012, (b) cotton (SI) in 2014, (c) maize (DI) in 2013, (d) maize (SI) in 2013, (e) maize (FIi) in 2012, and (f) maize (FI) in 2013. The dotted horizontal lines with triangle heads at both ends indicate the cropping season. Thick horizontal lines indicate periods when daily total $E$ values were gap-filled using the procedure explained in Supplementary material, Section 2.

Fig. 3 Time changes for $\theta, z_{\mathrm{rz}}$ (dotted line), and $z_{\mathrm{gw}}$ (solid lines) for selected summer crops, (a) rice (BI) in 2012, (b) cotton (SI) in 2014, (c) maize (DI) in 2013, (d) maize (SI) in 2013, (e) maize (FIi) in 2012, and (f) maize (FI) in 2013 (see Supplementary material, Section 3 for details of the $\theta$-measurements and processing; also see Supplementary material, Section 4 regarding the root zone depth of maize for $z_{\mathrm{rz}}$ ). 
The contour line for $\theta=0.45$ is shown with an orange color, and is close to the field capacity.

Fig.4 Changes in the daily values of $E, E_{0}, K_{\mathrm{ca}}$, and $P_{\mathrm{i}}$ for some of the selected winter crops, (a) faba beans (FI) in 2012-2013, (b) wheat (BI) in 2012-2013, (c) wheat (BI) in 2012-13, (d) sugar beets (FI) in 2013-14, (e) berseem (BI) in 2011-12, and (f) berseem (BIi) in 2013-14. See Fig. 2 for explanation.

Fig. 5 Time changes for $\theta, z_{\mathrm{rz}}$ (dotted line), and $z_{\mathrm{gw}}$ (solid lines) for selected winter crops, (a) faba beans (FI) in 2012-13, (b) wheat (BIi) in 2012-13, (c) wheat (BI) in 2012-13, (d) sugar beets (FI) in 2013-14, (e) berseem (BI) in 2011-12, and (f) berseem (BIi) in 2013-14. See Fig. 3 for explanation. 

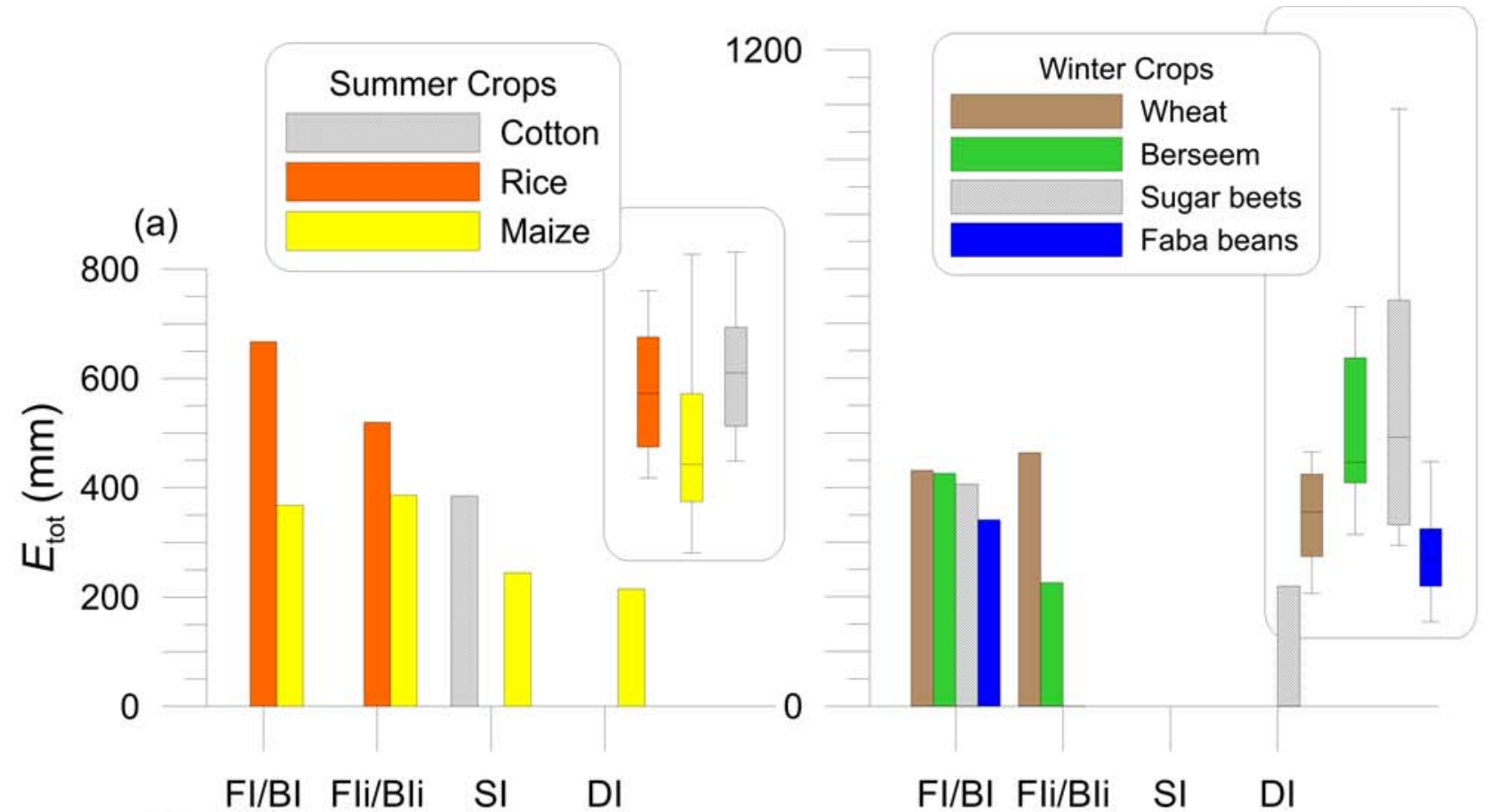

(b)
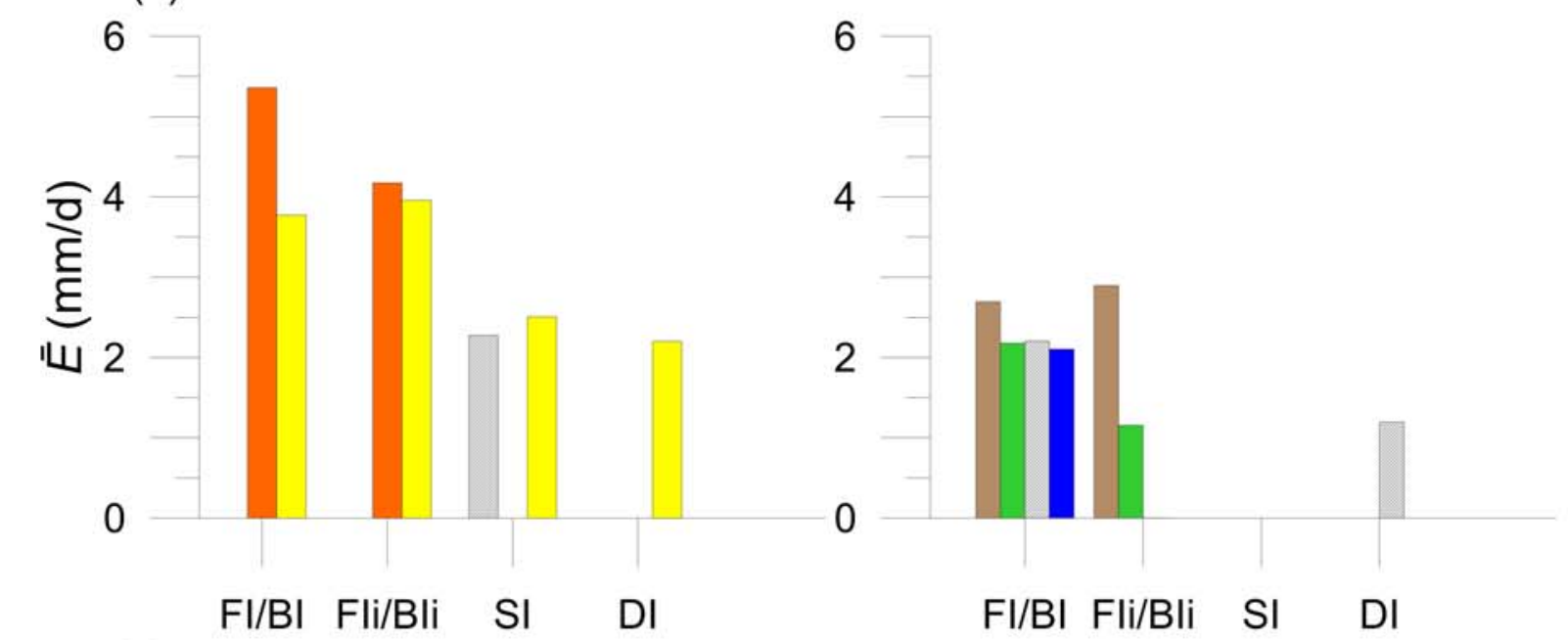

(c)
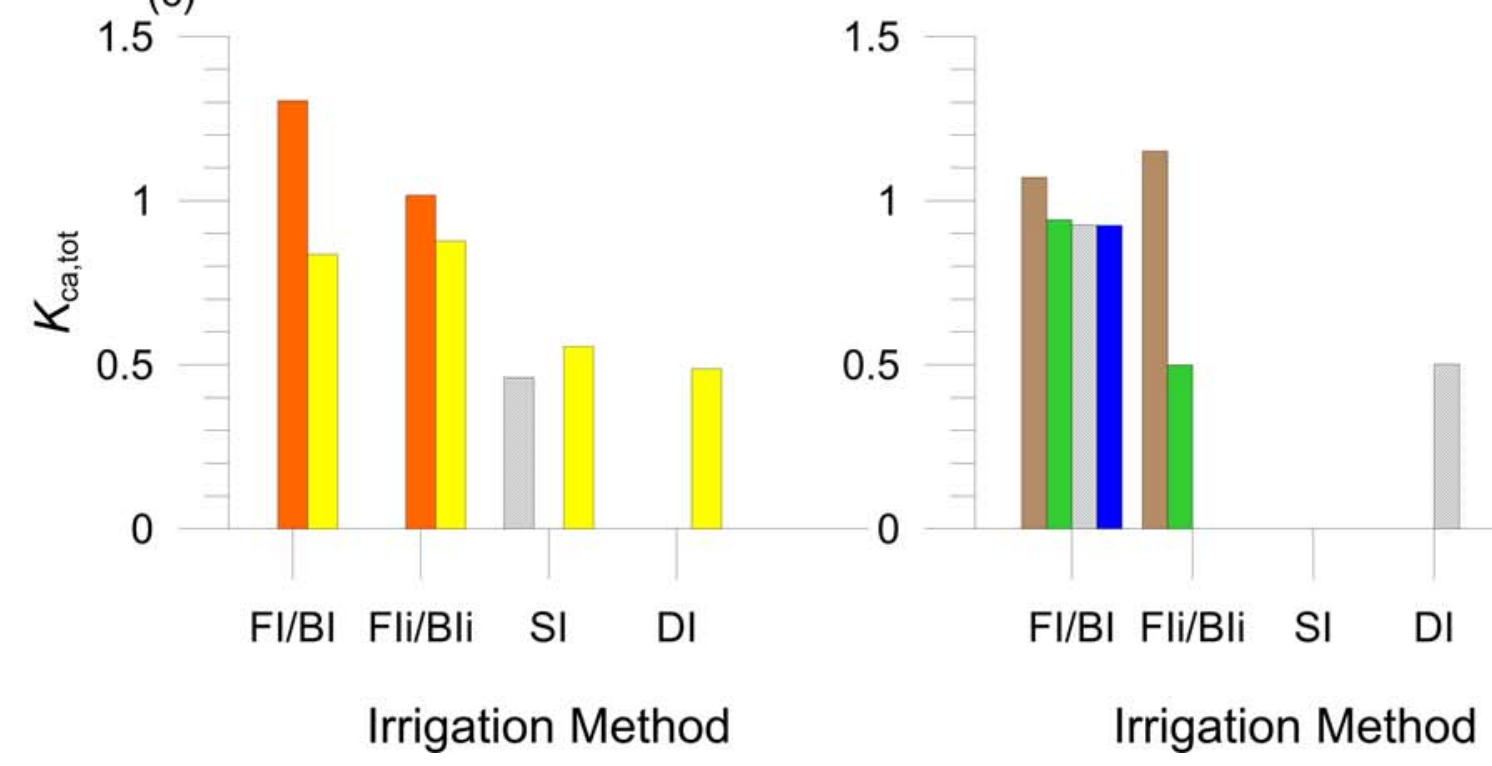


\section{$E----K_{\mathrm{ca}}=E / E_{0}$
$E_{0} \square P_{\mathrm{i}}$}

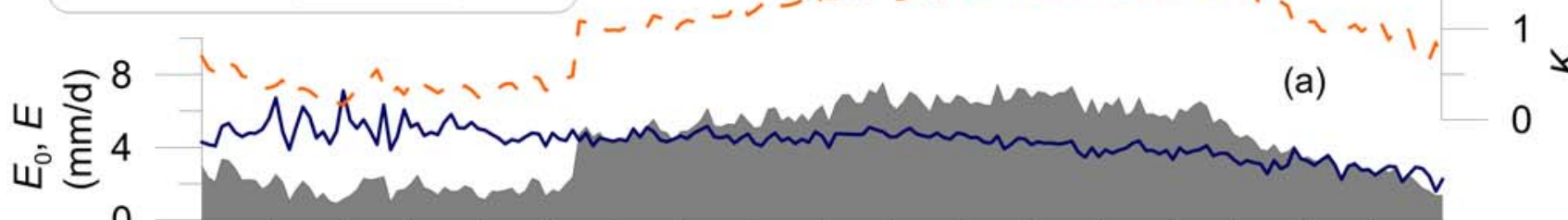

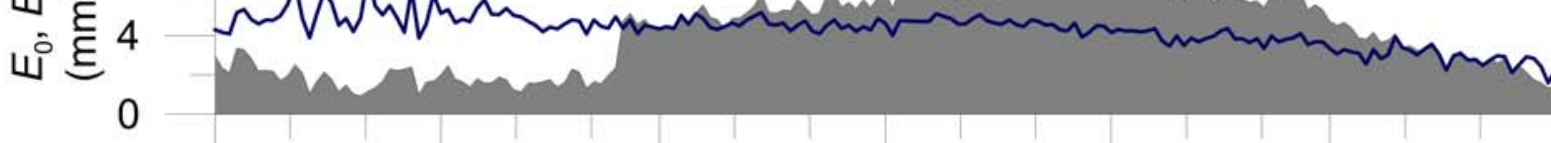

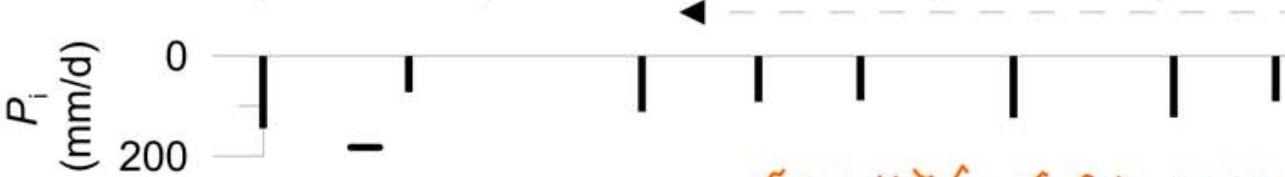

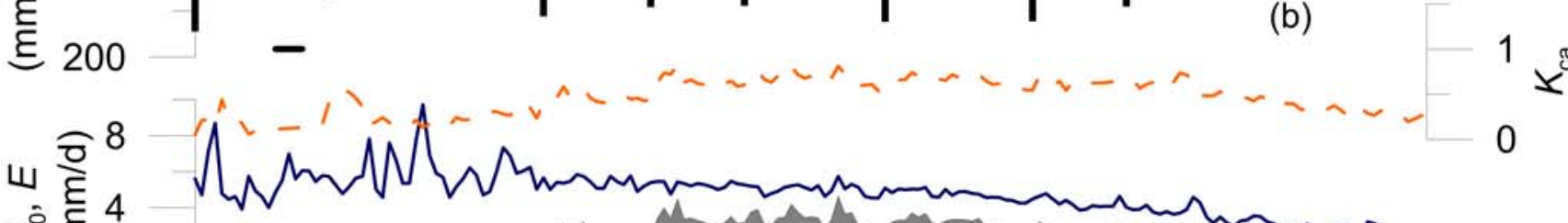
山ं 4 (N)

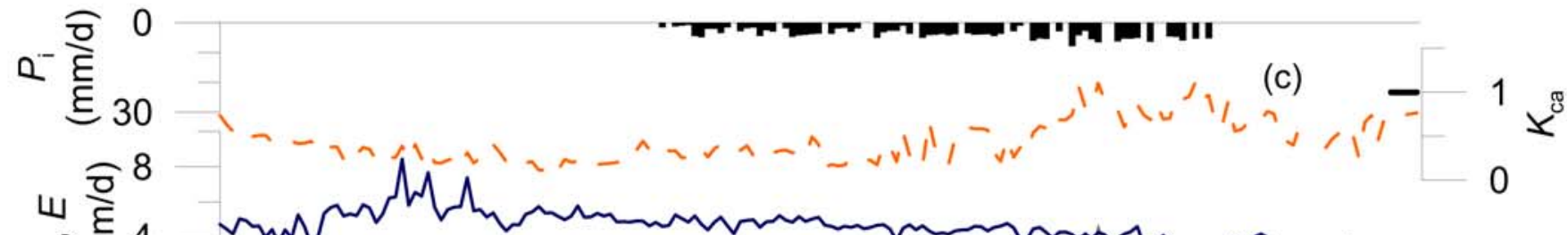

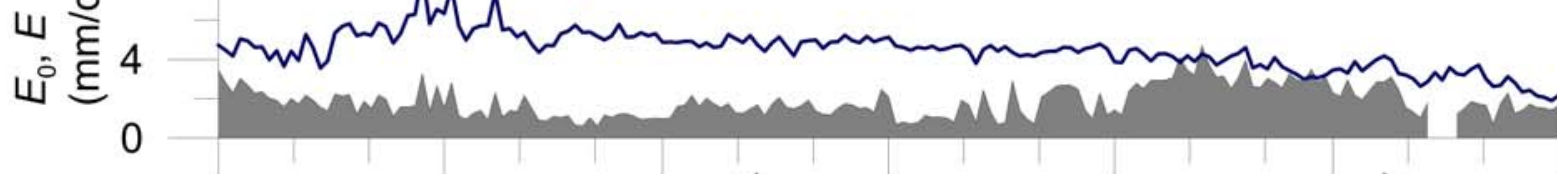

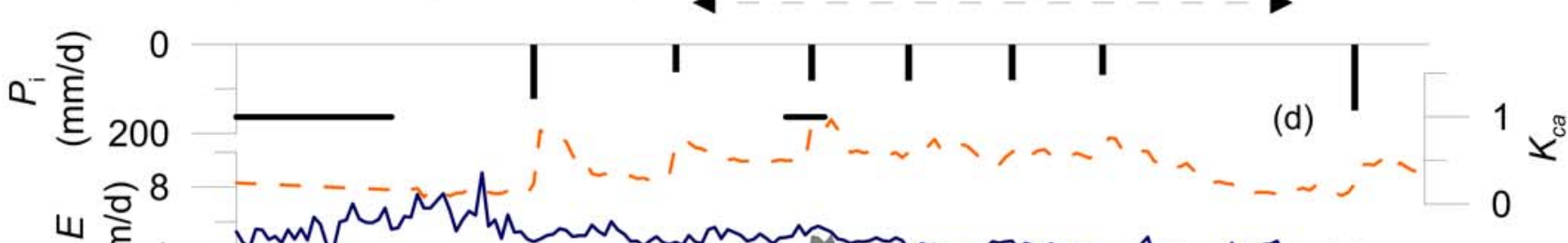

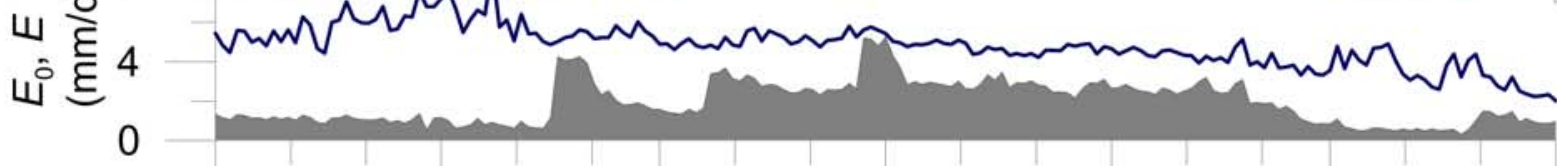

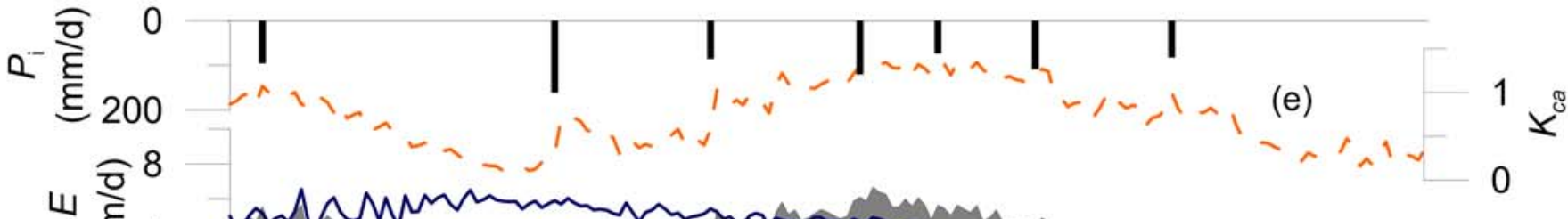

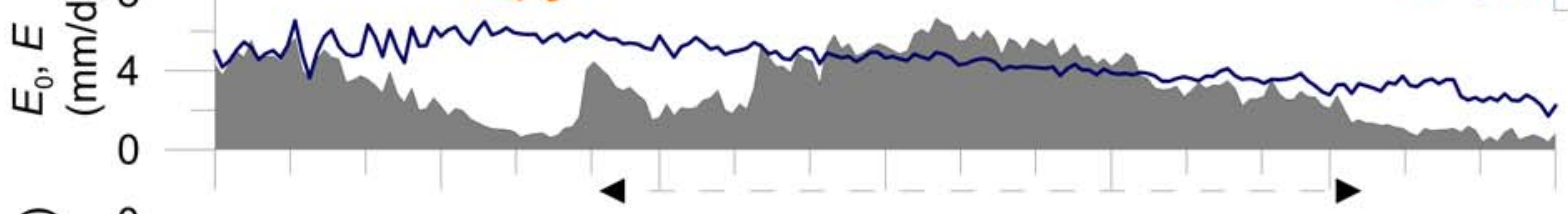

Q

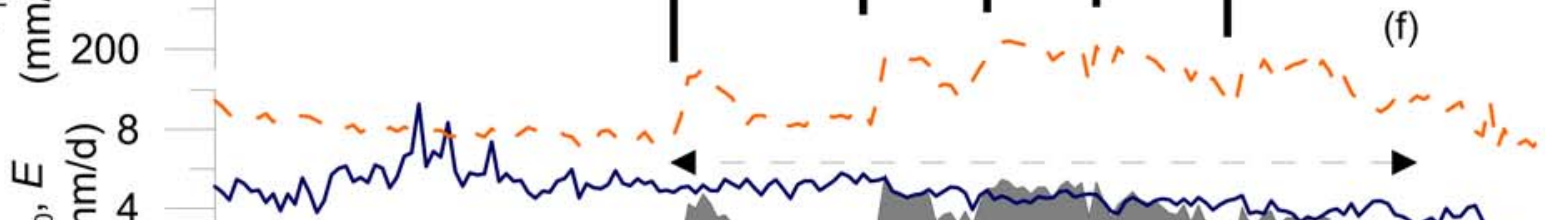
Li 4 E 4 Non 1 May 1 Jun 1 Jul 1 Aug 1 Sep 1 Oct 1 Nov 

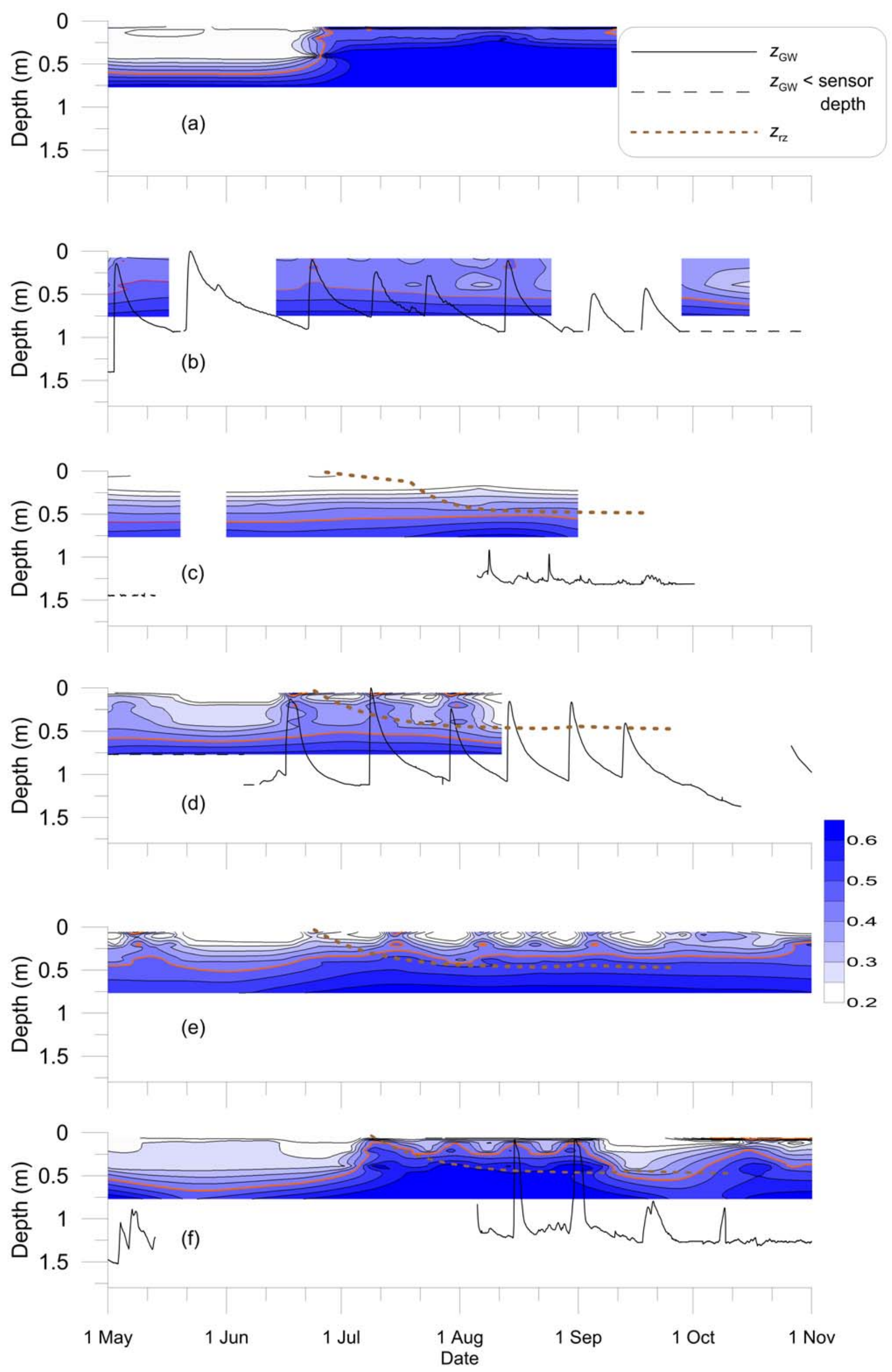


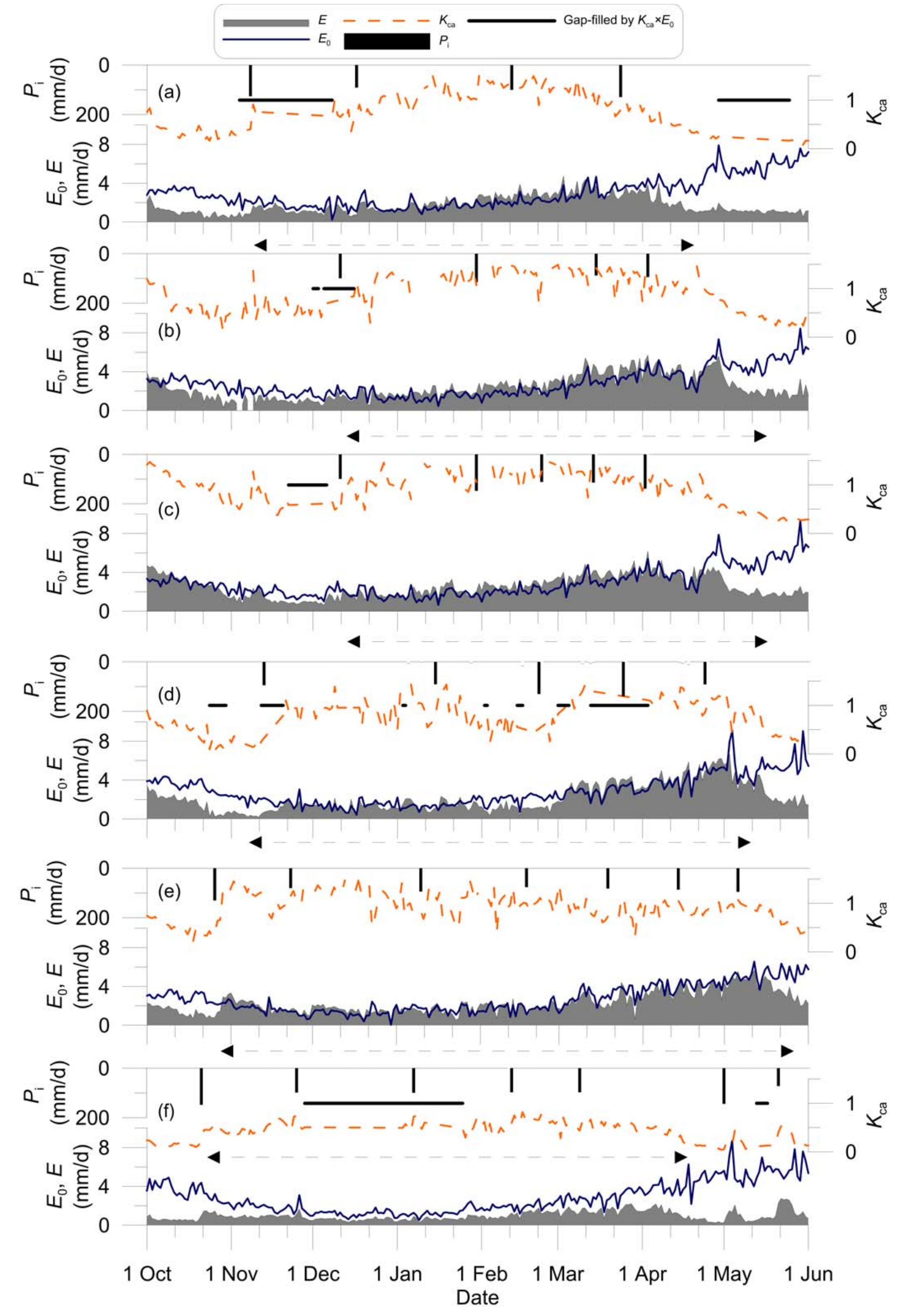



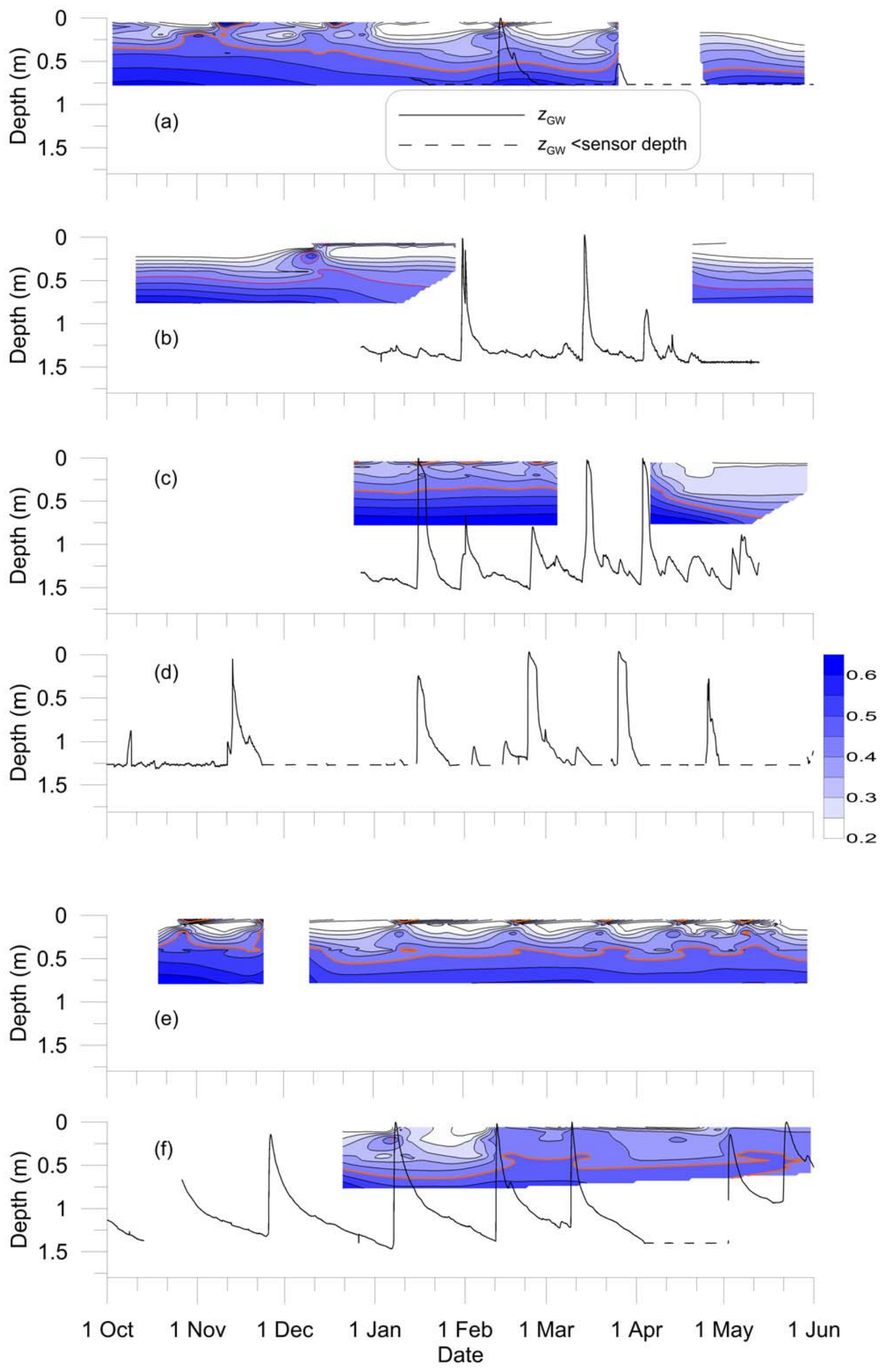
Crop evapotranspiration in the Nile Delta cultivated under different irrigation methods

Supplementary material

by Michiaki Sugita, Akihiro Matsuno, Rushdi M. M. El-Kilani, Ahmed Abdel-Fattah, and M.A. Mahmoud

\section{Spatial and temporal variability of climatic condition}

\subsection{Spatial variability}

Available information indicates that climate can be uniform over the croplands in the Nile Delta. For example, the air temperature, relative humidity and cloudiness were found to be about the same in different observation stations within the Delta (Shahin 1985). Moreover, a map of annual potential evapotranspiration (Shahin 1985) based on evaporation pan measurements and estimation formulae indicated that similar evaporative demand prevailed within the Delta, but increased demand was found near the coastal regions and outside the Delta. These areas that are different from the major portion of the Delta correspond to the areas that also have different soils from those in the main part of the Delta, and that has different landuse other than croplands, as mentioned in section 2.1.

From our observations at two locations, uniform climatic condition can be verified. The average annual values of air temperature $\overline{T_{a}}$, relative humidity $\bar{r}$, wind speed $\bar{u}$, and solar radiation $\overline{R_{\text {sd }}}$ in 2011-2013 were about the same at the two sites, with $\overline{T_{\mathrm{a}}}=19.8^{\circ} \mathrm{C}$ and $20.3^{\circ} \mathrm{C}, \bar{r}=75 \%, 69 \%, \bar{u}=2.5 \mathrm{~m} / \mathrm{s}$ and $2.1 \mathrm{~m} / \mathrm{s}$, and $\overline{R_{\mathrm{sd}}}=215 \mathrm{~W} / \mathrm{m}^{2}$ and $215 \mathrm{~W} / \mathrm{m}^{2}$ for the Sakha and Zankalon sites, respectively. The $T_{\mathrm{a}}$ values are also about the same with those in some other cities in the Delta (El-Kilani 
and Sugita 2017).

\subsection{Temporal variability}

The average monthly value and standard deviation in July observed at the

Sakha-A station were $\overline{T_{\mathrm{a}}}=26.4 \pm 0.5^{\circ} \mathrm{C}$ for air temperature, $\bar{r}=76.1 \pm 2.4 \%$ for relative humidity, $\bar{u}=2.8 \pm 0.2 \mathrm{~m} / \mathrm{s}$ for wind speeds, and $\overline{R_{\mathrm{sd}}}=286 \pm 13 \mathrm{~W} / \mathrm{m}^{2}$ for solar radiation in five years. In January, they were $\overline{T_{\mathrm{a}}}=12.5 \pm 0.8^{\circ} \mathrm{C}, \bar{r}=81.6 \pm 2.1 \%, \bar{u}=2.2 \pm 0.7$ $\mathrm{m} / \mathrm{s}$, and $\overline{R_{\mathrm{sd}}}=124 \pm 7 \mathrm{~W} / \mathrm{m}^{2}$ in four years. Clearly, year-to-year variations were small.

\section{Derivation of daily total fluxes}

\subsection{Turbulence data processing}

In the application of the eddy correlation method, first, the $10-\mathrm{Hz}$ raw data of the wind velocity components, the water vapor density and the sonic virtual temperature were used to calculate the mean, the variance, and the covariance of them, which were then subjected to the coordinate rotation to force the mean vertical wind velocity $\bar{w}=0$ over the averaging period of $30 \mathrm{~min}$, and to align the mean horizontal wind speed $\bar{u}$ to the mean wind direction so that wind velocity perpendicular to the mean wind direction should become $\bar{v}=0$. The derived 30-min covariance data were further subjected to correction methods such as the correction for the water vapor flux (Webb et al. 1980) and for the heat flux (Schotanus et al. 1983), and unit conversion. Finally, the covariances of $\overline{u^{\prime} w^{\prime}}, \overline{w^{\prime} t^{\prime}}, \overline{w^{\prime} q^{\prime}}$ were obtained, with $t$ indicating temperature, $q$ the 
specific humidity, $u$ the wind speed in the wind direction, and the overbar and prime the time averages and departure from them, and from which the 30-min time series data of evapotranspiration $E$, sensible heat flux $H$, and friction velocity $u_{*}$ were derived by

$$
\begin{gathered}
E=\rho \overline{w^{\prime} q^{\prime}} \\
H=\rho c_{\mathrm{p}} \overline{w^{\prime} t^{\prime}} \\
u_{*}=\left(-\overline{u^{\prime} w^{\prime}}\right)^{1 / 2}
\end{gathered}
$$

where $\rho$ is the density of the air, and $c_{\mathrm{p}}$ is the specific heat of air at constant pressure.

\subsection{Footprint analysis}

A two dimensional footprint analysis was carried out for maize with actual flux and meteorological data obtained in the summer cropping season of 2010 based on the method of Schuepp et al. (1990) with modification by Lloyd (1995) by incorporating stability effect and the function of the distance to the maximum relative flux density by Schmid and Oke (1990). Continuous 30-min footprint estimates $\Phi_{\mathrm{xy}}$ were weight averaged by corresponding evaporative fluxes $E$, and the integrated footprint over the

cropping season $\int E \Phi_{\mathrm{xy}} \mathrm{d} t / \int E \mathrm{~d} t$ was derived by following Ono (2008).

It was found that approximately $80 \%$ of the flux measured by the eddy correlation system during the cropping season originated from within the $200 \times 200-\mathrm{m}$ field. For other studied crops, this ratio is expected to be somewhat smaller as their crop height and roughness were smaller and thus the turbulent exchange was weaker. However, since the upwind areas were also similar crop fields, influence of fluxes 
originated from areas outside of the field on the measured fluxes should not be too large. The largest error could be expected in 2012 and 2014 when rice was cultivated in Sakha-A and maize in the downwind direction in the Sakha-B field, since evaporation and energy balance of the rice field were found quite different from those of maize (see section 3.1.1). Although no clear indication of contamination from the upwind areas was found in the data record obtained in the Sakha-B field in this setting, it was not used for the analysis presented in this study.

\subsection{Data quality check and gap filling}

Flux data were further examined for quality assurance (e.g., Lee et al. 2004, AsiaFlux Steering Committee 2007), and those judged questionable were rejected and then gap-filled by the following procedure. If only $H$ or $E$ was missing, then the energy balance equations

$$
\begin{aligned}
& H=R_{\mathrm{n}}-L_{\mathrm{e}} E-G \\
& L_{\mathrm{e}} E=R_{\mathrm{n}}-H-G
\end{aligned}
$$

were used to estimate the missing value. $R_{\mathrm{n}}$ is the net radiation, $G$ is the soil heat flux and $L_{\mathrm{e}}$ is the latent heat for vaporization. The number of the $H$ and $E$ data which had been gap-filled by this procedure was very small during daytime $(\leq 0.6 \%$ of each cropping season) and larger during night time ( $<3 \%$ for $H$ and $<19 \%$ for $E$ ) due to dew formation on the sensor head of the gas analyser. 
The remaining missing parts in the data were further gap filled by interpolation in time if the number of consecutive missing values was $N \leq 3$. The percentage of the $H$ and $E$ data which had been gap-filled by this procedure was $\leq 0.1 \%$ during daytime and $<0.6 \%$ during nighttime of each cropping season.

The derived fluxes were then subjected to the following equations to force energy balance closure to obtain the corrected $H$ and $E$ values as,

$$
\begin{gathered}
E=\frac{1}{L_{\mathrm{e}}(1+B o)}\left(R_{\mathrm{n}}-G\right) \\
H=\frac{B o}{1+B o}\left(R_{\mathrm{n}}-G\right)
\end{gathered}
$$

The Bowen ratio Bo was determined by $H /\left(L_{\mathrm{e}} E\right)$ with $H$ and $E$ from (S.1), (S.2), and (S.4). Thus the energy imbalance in the observed energy balance components was distributed into the turbulence fluxes of $H$ and $E$ by preserving the Bo values as suggested by Twine et al. (2000). Although this is the most common energy-closure adjustment procedure (e.g., Barr et al. 2012), there is an opinion against the use of it (e.g., Kowalski 2012) and the other procedures have also been proposed (e.g., Billesbach 2011). Since no consensus is available on this issue, the straightforward procedure, i.e., (S.5)-(S.6) was adopted. This has also advantage that it is consistent with the procedure outline above by (S.4). Note that the energy balance ratio $\left(\equiv \frac{\sum\left(L_{\mathrm{e}} E+H\right)}{\sum\left(R_{\mathrm{n}}-G\right)}\right)$ estimated over each cropping season before the application of (S.5) -(S.6) was 0.49-0.85 with the average of 0.64. This is within the range, but on a lower 
side, of the ratios reported in the literature (e.g., 0.53-0.99 by Wilson et al. (2002) over 22 flux sites, $0.57-1.0$ by Li et al. (2005) and Yu et al. (2006) for the China flux sites, 0.76-0.95 by Barr et al. (2012) for seven stations, and 0.28-1.67 by Stoy et al. (2013) for 173 sites.)

\subsection{Derivation of daily evapotranspiration}

The daily $E$ values were then derived from the 30-min averages obtained above. However, when the number of the 30 -min averages was $N<40$ within a day, the daily $E$ value on this day was not obtained from the 30-min averages, but was estimated by the following procedure. In this procedure, the reference crop evapotranspiration $E_{0}$ defined by the FAO (e.g., Allen et al. 1998; see also (1) in the main text), and the apparent crop coefficient $K_{\mathrm{ca}}\left(=E / E_{0}\right)$ were used to estimate the missing daily values of $E$ and then $H$ was estimated by (S.4).

In the gap-filling procedure, the daily $E_{0}$ and $K_{\text {ca }}$ values were determined several days before and after a gap and the averages of both were obtained. Then the daily $K_{\text {ca }}$ values that should correspond to the gap period were determined by a linear interpolation in time between the mean $K_{\text {ca }}$ value before the gap period and that after the period. The daily values of $E$ to be gap-filled were then estimated as $K_{\mathrm{ca}} \times E_{0}$.

When an irrigation event took place during the period to be gap-filled, the linear interpolation method outlined above is not appropriate. Thus in this case, the $K_{\text {ca }}$ values just before the irrigation event, and that just after the event were first determined 
by adopting the values at the time of nearest irrigation event. Those $K_{\text {ca }}$ values were then used together with the $K_{\text {ca }}$ values before and after the gap, to apply the linear interpolation scheme for the two separate periods, one prior to the irrigation event, and one after the event.

This method can be classified as a non-linear regression method (e.g., AsiaFlux Steering Committee 2007); however, the use of the reference crop evapotranspiration for the purpose of gap-filling is probably new. Thus its performance was tested with artificially made gaps with the lengths of $m=5,15,30$ and $60 \mathrm{~d}$ in arbitrarily selected continuous daily data records. The results indicated that the average rms difference between the gap-filled data and actual data for the $n$ records were $\overline{e_{\mathrm{rms}}}=\sum\left(\sum\left(E-K_{\mathrm{ca}} E_{0}\right)^{2} / m\right)^{1 / 2} / n=0.45 \pm 0.22 \mathrm{~mm} / \mathrm{d}$ for $m=5$ and $n=10, \overline{e_{\mathrm{rms}}}=$ $0.68 \pm 0.12 \mathrm{~mm} / \mathrm{d}$ for $m=15$ and $n=5, \overline{e_{\text {rms }}}=0.84 \pm 0.20 \mathrm{~mm} / \mathrm{d}$ for $m=30$ and $n=3$, and $\overline{e_{\mathrm{rms}}}=0.58 \pm 0.15 \mathrm{~mm} / \mathrm{d}$ for $m=60$ and $n=3$. The corresponding relative $\mathrm{rms}$ difference was respectively $\overline{R_{-} e_{\mathrm{rms}}}=\overline{\left(e_{\mathrm{rms}} / E\right)}=0.19 \pm 0.10, \overline{R_{-} e_{\mathrm{rms}}}=0.40 \pm 0.15$, $\overline{R_{-} e_{\mathrm{rms}}}=0.44 \pm 0.13$, and $\overline{R_{-} e_{\mathrm{rms}}}=0.28 \pm 0.26$.

The days that had been gap-filled by this procedure were $0-8 \%$ for most of the cropping season, with four exceptions of 12\% (winter crop, 2011-12, Zankalon), 19\% (winter crop, 2012-13, Zankalon), 26\% (winter crop, 2013-14, Sakha-A), and 33\% (winter crop, 2013-14, Zankalon). Those periods are indicated by the horizontal lines in Figs. 2 and 4. They were mainly caused by electricity problems during winter periods. 


\section{Soil water content data}

For soil water content measurements, a TDR100 system with CS630 proves was installed (Table 2) at each of the three fields. The 35 proves were installed as a 7 $\times 5$ array (Table 2) within a $0.8 \mathrm{~m}$ (width) by $0.8 \mathrm{~m}$ (depth) soil column in order to capture the spatial distribution of soil moisture. Unfortunately, the measurements failed quite often under high bulk EC conditions of $>1.7 \mathrm{dS} / \mathrm{m}$ approximately (Fujimaki, 2010-2015, personal comm.; Sugita et al. 2016). As such, the raw data were processed to produce the daily values of $\theta$ as much as possible by applying the following procedure. First, obvious questionable data were removed, and then the median value was determined for each sensor on each day. The results were plotted on a graph and visually examined to further remove questionable data by comparing the time changes of $\theta$ with the irrigation record and $z_{\mathrm{GW}}$. The resulting daily data were then subjected to a gap-fill procedure in which the missing parts were interpolated in time when the number of missing days was $N<3$ and no irrigation took place during this period. Additionally, only in the summer cropping season in 2014 in Zankalon, when $\theta$ values at the depth of $0.8 \mathrm{~m}$ were missing, they were gap-filled by assuming a constant $\theta$ value, which was determined as the mean value observed in the same field under the same irrigation method but in the summer of 2013. This method was judged acceptable as $\theta$ at $-0.8 \mathrm{~m}$ was found almost constant with $\theta=\theta_{\mathrm{s}}$ in 2013 due to closeness to the water table under the same irrigation method.

The seven sets of daily $\theta$ records obtained for the same depth could be separated into two groups, i.e., those with larger $\theta$ values (Group I) and those with 
smaller $\theta$ values (Group II) particularly at shallow depths. The larger $\theta$ values represent moisture status below furrow bottom or the drip emitters, while the smaller $\theta$ values below planting bed or soil surface away from the emitters. In Figs. 3 and 5, the selected $\theta$ data records at five depths are shown by further interpolated both in time and depth by a natural neighbor scheme. In the data record selection, those with the minimum data gaps were chosen from Group I for DI and SI, from Group II for FI and FIi and from all (BI and BIi) to better reflect water availability for the crop.

\section{Root zone depth of maize}

The root zone depth $z_{\mathrm{rz}}$ of maize was determined from the root distribution analysis of Tsuchihira (2011), and additionally from the data of Fujimaki (2014, personal comm.). Tsuchihira (2011) determined the dry root weight values within a soil block of $0.2 \times 0.2 \times 0.1 \mathrm{~m}$ from the surface to $-0.5 \mathrm{~m}$ at a $0.1-\mathrm{m}$ interval. They were used to derive the following functional relationships

$$
z_{\mathrm{rz}}= \begin{cases}0.483 \exp \left(-L_{\mathrm{A}} / 1.092\right)-0.49 & \left(\mathrm{FI}, \mathrm{FI}_{\mathrm{i}}, \text { and } \mathrm{SI}\right) \\ 0.550 \exp \left(-L_{\mathrm{A}} / 0.352\right)-0.56 & (\mathrm{DI})\end{cases}
$$

and were used to estimate the daily $z_{\mathrm{rz}}$ value from $L_{\mathrm{A}}$. For this purpose, periodic measurements of $L_{\mathrm{A}}$ were interpolated linearly in time to produce daily values. Also the $z_{\mathrm{rz}}$ time series estimated for 2010-2012 were used in 2013-2015 by assuming the same crop growth for the same irrigation method since the $L_{\mathrm{A}}$ data were not available 
after 2013 . 
5 Details of irrigation methods

Table S1 Details of irrigation methods

\begin{tabular}{|c|c|c|c|c|c|}
\hline $\begin{array}{l}\text { Irrigation } \\
\text { methods }\end{array}$ & $\begin{array}{l}\text { Number of sections } \\
\text { within a } 200 \times 200-\mathrm{m} \\
\text { field }\end{array}$ & $\begin{array}{l}\text { Planting bed } \\
\text { width }\end{array}$ & Furrow width & $\begin{array}{l}\text { Number of plants } \\
\text { raw on a bed }\end{array}$ & Remarks \\
\hline FI, FIi & 2 & $50 \mathrm{~cm}$ & $20 \mathrm{~cm}$ & $\begin{array}{l}\text { one at the center } \\
\text { of a bed }\end{array}$ & \\
\hline BI, BIi & 2 & N/A & N/A & N/A & \\
\hline SI & 2 & $\begin{array}{lr}100 & \mathrm{~cm} \\
\text { (maize } & \text { and } \\
\text { cotton) } & \end{array}$ & $\begin{array}{l}40 \mathrm{~cm} \text { (maize) } \\
30 \mathrm{~cm} \text { (cotton) }\end{array}$ & $\begin{array}{l}\text { two at both edges } \\
\text { of a bed }\end{array}$ & $\begin{array}{l}\text { Based on Atta (2006) designed for } \\
\text { rice cultivation, and revised for } \\
\text { cotton and maize. }\end{array}$ \\
\hline DI & 8 & N/A & N/A & N/A & $\begin{array}{l}5-\mathrm{m} \text { laterals with emitters at an interval } \\
\text { of } 0.2 \mathrm{~m} \text { were installed at } 0.9-\mathrm{m} \\
\text { interval in each section }\end{array}$ \\
\hline
\end{tabular}




\section{Crop and irrigation schedule}

Table S2 Crop and irrigation schedule

\begin{tabular}{|c|c|c|}
\hline Crop and plant density & $\begin{array}{l}\text { Irrigation } \\
\text { method }\end{array}$ & Planned irrigation amount and timing (days after seeding) \\
\hline Maize [Zea mays L., cv. Three Ways Cross (Hybrid) 324], 5.6 & FI & $160 \mathrm{~mm}(0), 80 \mathrm{~mm}$ (every 2 weeks); total $=720 \mathrm{~mm}$ \\
\hline \multirow[t]{5}{*}{ hills $/ \mathrm{m}^{2}$} & $\mathrm{FI}_{\mathrm{i}}$ & $160 \mathrm{~mm}(0), 80 \mathrm{~mm}(25,47,61,75$, and 96$) ;$ total $=560 \mathrm{~mm}$ \\
\hline & SI & $120 \mathrm{~mm}(0), 60 \mathrm{~mm}$ (every 2 weeks) ; total $=540 \mathrm{~mm}$ \\
\hline & DI & $10 \mathrm{~mm}$ (every $4 \mathrm{~d}$ for $1-30 \mathrm{~d})$ \\
\hline & & $35 \mathrm{~mm}$ (every $10 \mathrm{~d}$ for $31-60 \mathrm{~d})$ \\
\hline & & $45 \mathrm{~mm}$ (every $10 \mathrm{~d}$ after $61 \mathrm{~d}$ ); total $=320 \mathrm{~mm}$ \\
\hline Rice [Oryza sativa L., cv. Giza 178 (indica $\times$ japonica)], 25 hills $/ \mathrm{m}^{2}$ & $\mathrm{BI}$ & up to water depth of $3-6 \mathrm{~cm}$ (every $4 \mathrm{~d})$ \\
\hline Rice [Oryza sativa L., cv. Giza 179], 25 hills $/ \mathrm{m}^{2}$ & $\mathrm{BI}_{\mathrm{i}}$ & up to water depth of $5-6 \mathrm{~cm}$ (every $8 \mathrm{~d})$ \\
\hline Cotton [Gossypium barbadese L., cv. Giza 86], 6.1 plants $/ \mathrm{m}^{2}$ & SI & $\begin{array}{l}135 \mathrm{~mm}(0), 83 \mathrm{~mm}(21,42,56,70,84,98,112 \text {, and 126); } \\
\text { total }=799 \mathrm{~mm}\end{array}$ \\
\hline Wheat [Triticum aestivum L., cv. Giza 168], $9.5 \mathrm{~g}$ of seeds $/ \mathrm{m}^{2}(15-\mathrm{cm}$ & BI & $120 \mathrm{~mm}(0), 95 \mathrm{~mm}(28,56,84$, and 112$) ;$ total $=500 \mathrm{~mm}$ \\
\hline raw interval by a seeding machine) & $\mathrm{BI}_{\mathrm{i}}$ & $120 \mathrm{~mm}(0), 95 \mathrm{~mm}(42,84) ;$ total $=310 \mathrm{~mm}$ \\
\hline Sugar beet [Beta vulgaris L., cv. TOP], 11 hills $/ \mathrm{m}^{2}$ (FI) and 5.6 & FI & $120 \mathrm{~mm}(0), 95 \mathrm{~mm}$ (every $28 \mathrm{~d}$ ); total $=500 \mathrm{~mm}$ \\
\hline hills $/ \mathrm{m}^{2}(\mathrm{DI})$ & DI & $8 \mathrm{~mm}$ (every $4 \mathrm{~d})$; total $=298 \mathrm{~mm}$ \\
\hline Berseem [Trifolium alexandrinum L., cv. Gimez 1], $6.0 \mathrm{~g}$ of seeds $/ \mathrm{m}^{2}$ & $\mathrm{BI}$ & $180 \mathrm{~mm}(0), 110 \mathrm{~mm}(28,56,84$, and 112$) ;$ total $=620 \mathrm{~mm}$ \\
\hline (by hand broadcasting) & $\mathrm{BI}_{\mathrm{i}}$ & $180 \mathrm{~mm}(0), 110 \mathrm{~mm}(42,84$, and 126$) ;$ total $=510 \mathrm{~mm}$ \\
\hline Faba bean [Vicia faba., L., cv. Sakha 1], 13 hills $/ \mathrm{m}^{2}$ & FI & $120 \mathrm{~mm}(0), 94 \mathrm{~mm}(35,77,119)$; total $=402 \mathrm{~mm}$ \\
\hline
\end{tabular}




\section{Previous studies on crop evapotranspiration measurements}

Table S3 Previous studies on crop evapotranspiration measurements

\begin{tabular}{lllll}
\hline $\begin{array}{l}\text { Crop } \\
\text { Location }\end{array}$ & $\begin{array}{l}\text { Number of } \\
E_{\text {tot values }}\end{array}$ & Experimental period & $\begin{array}{l}\text { Method of } E_{\text {tot }} \\
\text { measurements }\end{array}$ & References \\
\hline $\begin{array}{l}\text { Berseem } \\
\text { Marathwada, India }\end{array}$ & 16 & $1983-1985$ & Water balance & Mundhe and Shelke (1993), \\
Jhansi, India & 3 & $1991-1995$ & Lysimeter & Behari and Singh (1998) \\
Karnal, India & 2 & $1996-1998$ & Lysimeter & Tyagi et al. (2003) \\
Lahore, Pakistan & 4 & 10 years & Water balance & Kahlown et al. (2005) \\
Jhansi, India & 2 & $2009-2011$ & Lysimeter & Singh et al (2012) \\
Faba bean & 2 & & Water balance & Husain et al. (1990) \\
Canterbury, NZ & 8 & 1982 & Water balance & Rengasamy and Reid (1993) \\
Canterbury, NZ & 11 & $1984-1987$ & Water balance & Silim and Saxena (1993) \\
Tel Hadya, Syria & 3 & $1986-1988$ & Water balance & Izaurralde et al. (1994) \\
Two sites in Alberta, & & &
\end{tabular}




\begin{tabular}{|c|c|c|c|c|}
\hline Seven sites in Australia & 12 & 1993-1994 & Water balance & Loss et al. (1997) \\
\hline Bari, Italy & 9 & 1989-1998 & Lysimeter & Katerji et al. (2003) \\
\hline Tel Hadya, Syria & 48 & $1996-2000$ & Water balance & Oweis et al. (2005) \\
\hline Roseworthy, Australia & 6 & $\begin{array}{l}\text { 1994-1995, } \\
1997-1998\end{array}$ & Water balance & Yunusa and Rashid (2007) \\
\hline Merredin, Autstralia & 15 & $1997-1998$ & Water balance & French (2010) \\
\hline Bari, Italy & 6 & $2007-2009$ & Lysimeter & Katerji et al. (2011) \\
\hline Aleppo in Syria & 12 & $2007-2010$ & Water balance & Karou and Owes (2012) \\
\hline \multicolumn{5}{|l|}{ gar beet } \\
\hline Sufforlk, UK & 24 & $1980-1991$ & Water balance & $\begin{array}{l}\text { Brown et al. (1987) and } \\
\text { Werker and Jaggard (1998) }\end{array}$ \\
\hline Kahramanmaraß, Turkey & 12 & $1999-2000$ & Water balance & Uçan and Gençoğlan (2004) \\
\hline Bari, Italy & 6 & $1989-1998$ & Lysimeter & Katerji et al. (2003) \\
\hline Foggia, Italy & 6 & $1998-2002$ & Water balance & Rinaldi and Vonella (2006) \\
\hline Erzurum, Turkey & 2 & 2003-2004 & Water balance & Sahin et al. (2007) \\
\hline Konya, Turkey & 4 & $2005-2006$ & Water balance & Topak et al. (2011) \\
\hline
\end{tabular}

n/a: not available 
8 Cultivated areas for the summer crop (a) and winter crops (b)
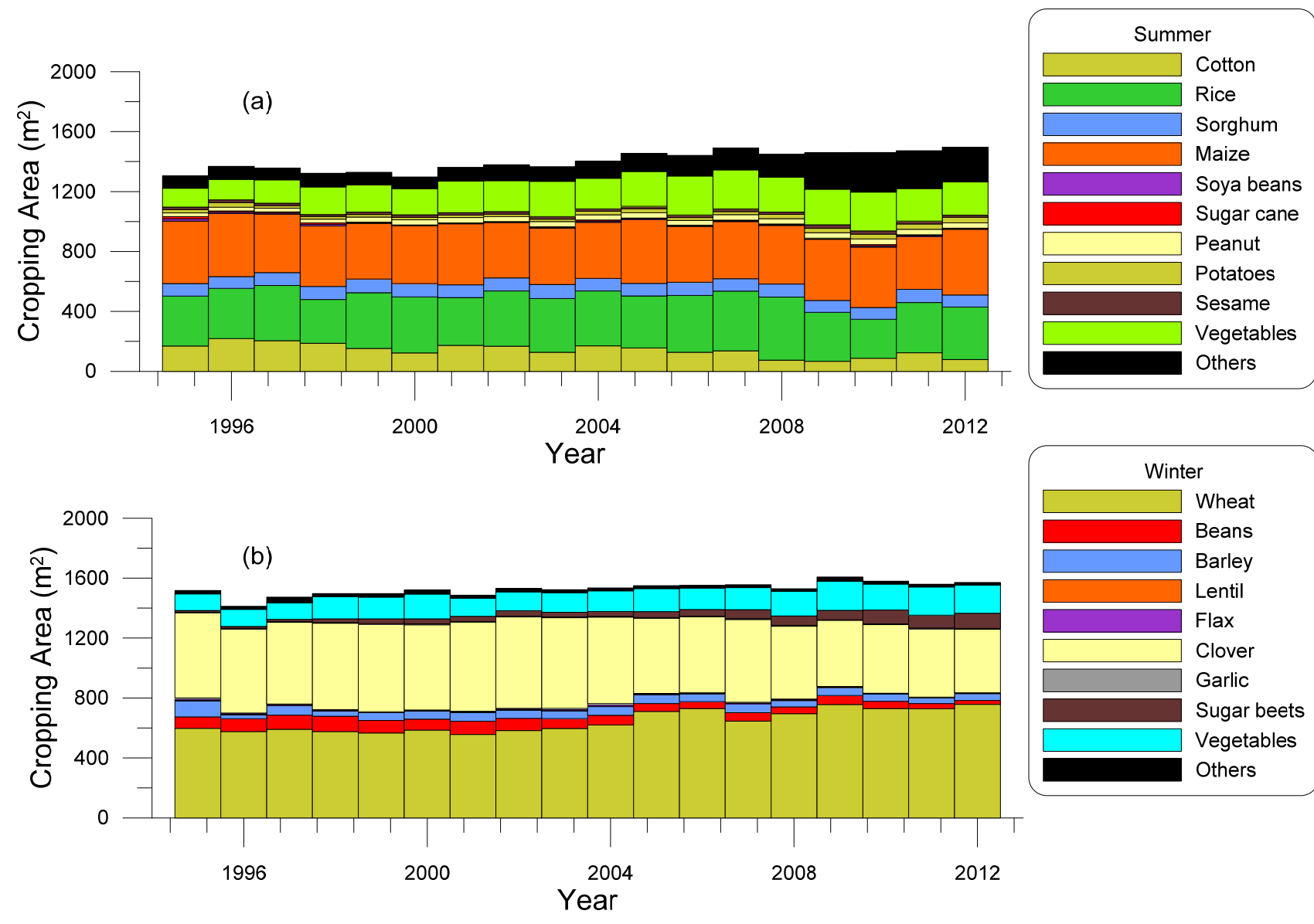

Fig. S1 Cultivated areas for the summer crop (a) and winter crops (b) based on statistics given in Central Agency for Public Mobilization and Statistics (2014). 


\section{REFERENCES}

Allen, R.G., et al., 1998. Crop evapotranspiration - guidelines for computing crop water requirements. FAO Irrigation and Drainage Paper 56, Food and Agriculture Organization of the United Nations: Rome, Italy. (also Available from: http://www.fao.org/docrep/x0490e/x0490e00.htm\#Contents [Accessed 1 December 2016])

AsiaFlux Steering Committee, ed., 2007. Practice of Flux Observations in Terrestrial Ecosystems. Available for AsiaFlux members from: http://www.asiaflux.net/ [Accessed 3 February, 2016].

Atta, Y.I., 2006. A new method for cultivating rice with high potential for water saving. Grid-IPTRID Magazine, 25, 10-12.

Barr, A.G., et al., 2012. Energy balance closure at the BERMS flux towers in relation to the water balance of the White Gull Creek watershed 1999-2009. Agricultural and Forest Meteorology, 153, 3-13, doi:10.1016/j.agrformet.2011.05.017

Behari, P. and Singh, J.B., 1998. Evapo-transpiration and water-use efficiency of berseem (Trifolium alexandrinum) in a semi-arid region. The Indian Journal of Agricultural Sciences, 68, 123-124.

Billesbach, D.P., 2011. Estimating uncertainties in individual eddy covariance flux measurements: a comparison of methods and a proposed new method. Agricultural and Forest Meteorology. 151, 394-405, doi:10.1016/j.agrformet.2010.12.001.

Brown, K.F., McGowan, M. and Armstrong, M.J., 1987. Response of the components of sugar beet leaf potential to a drying soil profile. The Journal of Agricultural Science, 109, 437-444. 
El-Kilani, R.M.M. and Sugita, M., 2017. Irrigation methods and water requirements in the Nile Delta. In: M. Satoh and S. Aboulroos, eds. Irrigated Agriculture in Egypt- Past, Present and Future. Springer, 125-151, doi: 10.1007/978-3-319-30216-4_6.

French, R.J., 2010. The risk of vegetative water deficit in early-sown faba bean (Vicia faba L.) and its implications for crop productivity in a Mediterranean-type environment. Crop and Pasture Science, 61, 566-577.

Husain, M.M., et al., 1990. Growth and water use of faba beans (Vicia faba) in a sub-humid climate I. Root and shoot adaptations to drought stress. Field Crops Research, 23, 1-17.

Izaurralde, R.C., Chanasyk, D.S., Juma, N.G., 1994. Soil water under conventional and alternative cropping systems in cryoboreal subhumid central Alberta. Canadian Journal of Soil Science, 74, 85-92.

Kahlown, M.A., et al., 2005. Effect of shallow groundwater tableon crop water requirement and crop yields. Agricultural Water Management, 76, 24-35

Karrou, M. and Oweis, T., 2012. Water and land productivities of wheat and food legumes with deficit supplemental irrigation in a Mediterranean environment. Agricultural Water Management, 107, 94-103.

Katerji, N., et al., 2003. Salinity effect on crop development and yield, analysis of salt tolerance according to several classification methods. Agricultural Water Management, 62, 37-66.

Katerji, N., et al., 2011. Faba bean productivity in saline-drought conditions. European 
Journal of Agronomy, 35, 2-12.

Kowalski, A., 2012. Exact averaging of atmospheric state and flow variables. Journal of the Atmospheric Sciences, 69, 1750-1757, doi: 10.1175/JAS-D-11-0299.1.

Lee, X., Massan, W. and Law, B., 2004. Handbook of Micrometeorology. the Netherland: Kluwer Academic Publ.

Li, Z.Q., et al., 2005. Energy balance closure at ChinaFLUX sites. Science in China Series D-Earth Sciences, 48, 51-62, doi: 10.1360/05zd0005.

Lloyd, C.R., 1995. The effect of heterogeneous terrain on micrometeorological flux measurements: a case study from HAPEX-Sahel. Agricultural and Forest Meteorology, 73, 209-216. doi:10.1016/0168-1923(94)05075-H

Loss, S.P., Siddique, K.H.M.and Tennant, D., 1997. Adaptation of faba bean (Vicia $f a b a$ L.) to dryland Mediterranean-type environments III. Water use and water use efficiency. Field Crops Research, 54, 153-162.

Mundhe, P.R. and Shelke, V.B. 1993. Water requirement of the berseem in Marathwada: an application of climatological approach. Journal of Maharashtra Agricultural University, 18, 270-272.

Ono, K. 2008. The eddy correlation method to investigate $\mathrm{CO}_{2}$ and water vapor fluxes of rice paddy ecosystem. Thesis (Ph.D), School of Life and Environmental Sciences, University of Tsukuba, Tsukuba, Japan (in Japanese).

Oweis, T., Hachum, A. and Pala, M., 2005. Faba bean productivity under rainfed and supplemental irrigation in northern Syria. Agricultural Water Management, 73, $57-72$. 
Rengasamy, J.I. and Reid, J.B., 1993. Root-System Modification of Faba Beans (Vicia-Faba L), and its Effects on Crop Performance .2. Role of Water-Stress. Field Crops Research, 33, 197-215.

Sahin, U., et al., 2007. Determining crop and pan coefficients for sugar beet and potato crops under cool season semiarid climatic conditions. Journal of Agronomy and Crop Science, 193, 146-152.

Schmid, H.P., Oke, T.R.. 1990. A model to estimate the source area contributing to turbulent exchange in the surface layer over patchy terrain. Quarterly Journal of the Royal Meteorological Society, 116, 965-988, doi: 10.1002/qj.49711649409.

Schotanus, P., Nieuwstadt, F.T.M. and De Bruin, H.A.R., 1983. Temperature measurement with a sonic anemometer and its application to heat and moisture fluxes. Boundary-Layer Meteorology, 26, 81-93

Schuepp, P.H., et al., 1990. Footprint prediction of scalar fluxes from analytical solutions of the diffusion equation. Boundary-Layer Meteorology, 50, 355-373. doi: 10.1007/BF00120530

Shahin, M., 1985. Hydrology of the Nile Basin. Netherlands: Elsevier Science Publ. B.V.

Singh, J.B., et al., 2012, Evapotranspiration and water use efficiency of hybrid napier + berseem intercropping system under organic and inorganic nutrition. Journal of Agrometeorology, 14, 130-133. 
Stoy, P.C., et al, 2013. A data-driven analysis of energy balance closure across FLUXNET research sites: The role of landscape scale heterogeneity. Agricultural and Forest Meteorology, 171-172, 137-152, doi:10.1016/j.agrformet.2012.11.004

Sugita, M., et al., 2016. Continuous soil moisture monitoring under high salinity conditions by dielectric sensors: a reliability test. Tsukuba Geoenvironmental Sciences, 12, 17-22. Available from: http://hdl.handle.net/2241/00144875 [Accessed 6 March 2017]

Tsuchihira, K., 2011. The estimation of evaporation and transpiration using hydrologic model in crop land of Nile Delta of Egypt. Thesis (MS), Graduate School of Life and Environmental Science, University of Tsukuba, Japan. (in Japanese)

Twine, T.E., et al., 2000. Correcting eddy-covariance flux underestimates over a grassland. Agricultural and Forest Meteorology, 103, 279-300, doi:10.1016/S0168-1923(00)00123-4

Tyagi, N.K., Sharma, D.K. and Luthra, S.K., 2003. Determination of evapotranspiration for maize and berseem clover. Irrigation Science, 21, 173-181.

Uçan, K, and Gençoğlan, C., 2004. The effect of water deficit on yield and yield components of sugar beet. Turkish Journal of Agriculture and Forestry, 28, 163-172.

Webb, E., Pearman, G.I. and Leuning, R., 1980. Correction of flux measurements for density effects due to heat and water-vapor transfer. Quarterly Journal of the Royal Meteorological Society, 106, 85-100, doi:10.1002/qj.49710644707.

Werker, A.R. and Jaggard, K.W., 1998. Dependence of sugar beet yield on light interception and evapotranspiration. Agricultural and Forest Meteorology, 89, 229- 
240.

Wilson, K., et al., 2002. Energy balance closure at FLUXNET sites. Agricultural and Forest Meteorology, 113, 223-243, doi:10.1016/S0168-1923(02)00109-0

Yu, G.-R., et al., 2006, Overview of ChinaFLUX and evaluation of its eddy covariance measurement. Agricultural and Forest Meteorology, 137, 125-137, doi:10.1016/j.agrformet.2006.02.011

Yunusa, I.A.M. and Rashid, M.A., 2007. Productivity and rotational benefits of grass, medic pastures and faba beans in a rainfall limited environment. Soil \& Tillage Researh, 97, 150-161. 